\title{
Review \\ Heart Failure and Diabetes Mellitus: Biomarkers in Risk Stratification and Prognostication
}

\author{
Michael Lichtenauer ${ }^{1}$, Peter Jirak ${ }^{1}$, Vera Paar ${ }^{1}$, Brigitte Sipos ${ }^{1}$, Kristen Kopp ${ }^{1}$ and Alexander E. Berezin ${ }^{2, *} \mathbb{D}$ \\ 1 Department of Internal Medicine II, Division of Cardiology, Paracelsus Medical University Salzburg, \\ 5020 Salzburg, Austria; m.lichtenauer@salk.at (M.L.); p.jirak@salk.at (P.J.); v.paar@salk.at (V.P.); \\ b.sipos@salk.at (B.S.);k.kopp@salk.at (K.K.) \\ 2 Internal Medicine Department, State Medical University, Ministry of Health of Ukraine, \\ 69035 Zaporozhye, Ukraine \\ * Correspondence: aeberezin@gmail.com
}

Citation: Lichtenauer, M.; Jirak, P.; Paar, V.; Sipos, B.; Kopp, K.; Berezin, A.E. Heart Failure and Diabetes Mellitus: Biomarkers in Risk Stratification and Prognostication Appl. Sci. 2021, 11, 4397. https:// doi.org/10.3390/app11104397

Academic Editor: Elena

G. Govorunova

Received: 11 April 2021

Accepted: 10 May 2021

Published: 12 May 2021

Publisher's Note: MDPI stays neutral with regard to jurisdictional claims in published maps and institutional affiliations.

Copyright: (c) 2021 by the authors. Licensee MDPI, Basel, Switzerland This article is an open access article distributed under the terms and conditions of the Creative Commons Attribution (CC BY) license (https:// creativecommons.org/licenses/by/ $4.0 /)$.

\begin{abstract}
Heart failure (HF) and type 2 diabetes mellitus (T2DM) have a synergistic effect on cardiovascular (CV) morbidity and mortality in patients with established CV disease (CVD). The aim of this review is to summarize the knowledge regarding the discriminative abilities of conventional and novel biomarkers in T2DM patients with established HF or at higher risk of developing HF. While conventional biomarkers, such as natriuretic peptides and high-sensitivity troponins demonstrate high predictive ability in HF with reduced ejection fraction (HFrEF), this is not the case for HF with preserved ejection fraction (HFpEF). HFpEF is a heterogeneous disease with a high variability of CVD and conventional risk factors including T2DM, hypertension, renal disease, older age, and female sex; therefore, the extrapolation of predictive abilities of traditional biomarkers on this population is constrained. New biomarker-based approaches are disputed to be sufficient for improving risk stratification and the prediction of poor clinical outcomes in patients with HFpEF. Novel biomarkers of biomechanical stress, fibrosis, inflammation, oxidative stress, and collagen turnover have shown potential benefits in determining prognosis in T2DM patients with HF regardless of natriuretic peptides, but their role in point-to-care and in routine practice requires elucidation in large clinical trials.
\end{abstract}

Keywords: heart failure; heart failure with reduced ejection fraction; heart failure with preserved ejection fraction; diabetes mellitus; circulating biomarkers; prognosis

\section{Introduction}

Due to the growing prevalence of diabetes worldwide, an increased incidence of premature deaths attributable to both diabetes as well as its complications is consequently to be expected [1]. In 2017, approximately five million deaths in both developed and developing countries were reported which can directly be related to diabetes [1]. The most common cardiovascular (CV) manifestations in individuals with type 2 diabetes mellitus (T2DM) included heart failure (HF), peripheral arterial disease, and coronary heart disease [2]. Prevalence of HF in the patient population with established T2DM is twofold higher than in those without the disease [3,4]. The Reykjavík Study has shown an overall prevalence of T2DM and HF of $0.5 \%$ in men and $0.4 \%$ in women [5]. Therefore, the odds ratio (OR) for the association between T2DM and $\mathrm{HF}$ is $2.8(95 \% \mathrm{CI}=2.2-3.6)$ and between abnormal glucose regulation and $\mathrm{HF}$ it is 1.7 (95\% CI $=1.4-2.1)$ [5].

Fatal and non-fatal CV outcomes, a risk of urgent hospitalization, and both short-term and long-term prognoses are sufficiently worse for T2DM patients when compared with those without T2DM [6]. T2DM development coincides with numerous structural and functional changes in the heart, vessels, skeletal muscles, adipose tissue, kidney, and other target organs, which in the presence of traditional CV risk factors contribute to increased HF risk [7,8]. Numerous clinical trials have revealed the synergistic effect of managing both 
HF and T2DM on their prognosis and clinical course [9-11]. In this context, biomarkers that reflect various pathophysiological stages of T2DM progression might have promising potential in guiding therapies. In addition, biomarkers offer important diagnostic and predictive information, which cannot be derived from clinical observation or objective data evaluation $[12,13]$. The aim of the review is to summarize knowledge about the discriminative abilities of conventional and novel biomarkers in T2DM patients at higher risk of or with established HF.

\section{Basic Underlying Mechanisms of HF Development in Diabetics}

Cardiac dysfunction in T2DM is a result of the development of metabolic abnormalities, attributed to increase fasting glucose, insulin resistance, lipotoxicity, and impaired reparation, sometimes termed diabetic cardiomyopathy, although not widely used [14]. Other causes for the occurrence of HF in diabetics include conventional CV risk factors that include hypertension, dyslipidemia, abdominal obesity, asymptomatic atherosclerosis, CVD, chronic kidney disease (CKD), as well as non-traditional risk factors, such as ectopic calcification and osteoporosis [15-17]. Consequently, cardiac dysfunction in T2DM patients is characterized by primary metabolic disturbances, secondary ischemic injury, cardiac myocyte apoptosis, immunological alterations with subsequent subcellular component abnormalities (mitochondrial stress, endoplasmic reticular formation dysfunction, secretome shaping impairment), oxidative stress with reduced nitric oxide bioavailability, fibrosis, local myocardial and microvascular inflammation, impaired cellular signaling (altered calcium homeostasis, activation of the sympathetic nervous system and the renin-angiotensin-aldosterone system (RAAS)), endothelial dysfunction, and altered tissue reparation [16,17].

In fact, impaired glucose metabolism, lipotoxicity, altered metabolic memory, and insulin resistance are considered as key factors contributing to mitochondrial stress and myocardial cell injury $[17,18]$. Indeed, suppressed AMP kinase activity due to mitochondrial dysfunction and consequently lowered phosphorylation of troponin relates to diastolic dysfunction prior to systolic dysfunction beyond the turnover of myosin chain isoforms [19]. In addition, impaired diabetic cardiac function is a result of insulin-dependent activation of phosphatidylinositol 3-kinase (PI3K)/ protein kinase B-ACT signaling, which alters titin phosphorylation and consequently leads to titin N2B/N2BA isoform modification and titin-based myocardial stiffness $[20,21]$. There is a large body of evidence regarding the fact that insulin can directly stimulate the expression of a number of hypertrophic genes in cardiac myocyte including $\beta$-myosin heavy chain, insulin-like growth factor 1 receptor, myocyte enhancement factor, and brain-type natriuretic peptide (BNP) [22-24]. Moreover, insulin-like growth factor 1 , acting directly as an activator of the insulin receptor and indirectly through extracellular signal-regulated kinase 2 (Erk1/2) and PI3K signaling pathways, mediates cardiac hypertrophy, extracellular remodeling, and suppresses cardiac myocyte apoptosis $[25,26]$.

The development of cardiac dysfunction in T2DM is closely associated with hyperactivity of both the RAAS and sympatico-adrenal nervous system (SNS) [27]. Acting as triggers of gluconeogenesis, lipolysis, and glycolysis, catecholamines, angiotensin-II and aldosterone promote the production of advanced glycation end products (AGE), which directly and along with insulin and glucose activate transforming growth factor beta 1 (TGF$\beta 1$ )/SMAD signaling pathways through appropriate cell surface receptors (RAGE) [28]. Consequently, increased oxidative stress, inflammatory response, and fibrotic extracellular matrix transformation with collagen cross-linking correspond to adverse cardiac remodeling, acceleration of atherosclerosis, and worsening vascular integrity and endothelial function [29-31]. Of note, impaired GLUT4 and PI3K/Akt/eNOS signaling due to the activation of RAAS and insulin resistance accompany the reduced tyrosine phosphorylation of insulin receptor substrate (IRS) $-1 / 2$, which in turn leads to a lowered nitric oxide production. It directly impairs the vasomotor ability of coronary arteries, and substantially 
decreases in the recruitment, proliferation, and survival of endothelial progenitor cells that play a pivotal role in endogenous vascular reparation [32].

Metabolic stress-induced pro-inflammatory activation has been cited as a powerful factor contributing to the pathogenesis of T2DM cardiomyopathy and HF [33]. Numerous inflammatory cytokines, such as tumor necrosis factor-alpha (TNF- $\alpha$ ), interleukin-6, as well as some adipocytokines, act as triggers for insulin resistance via the enhancement of nuclear factor kappa-light-chain-enhancer of activated B cells (NF-kB) and fork-head box-containing protein $\mathrm{O}$ subfamily (FoxO1) expression, as well as c-Jun $\mathrm{N}$ terminal kinase (JNK) activation, that induce the phosphorylation of IRS-1 and hamper the activation of peroxisome proliferator-activated receptors (PPAR)- $\gamma$ receptors [34,35]. These perturbations mediate insulin resistance of the myocardium and skeletal muscles, adipose tissue inflammation, markedly reduce an interaction of FoxO1 with the promoter region of the $\beta$-isoform of myosin heavy chain ( $\beta$-MHC) as well as negatively regulate $\beta$-MHC gene expression [36].

The structure and functional abnormalities result in adverse cardiac remodeling such as diastolic and systolic dysfunction due to cardiac hypertrophy, extracellular matrix accumulation and interstitial fibrosis, resulting in progressive dilated cardiomyopathy and decreased cardiac output, eventually leading to HF [37]. The underlying pathophysiological mechanisms contributing to the development of HF in DM are reported in Figure 1.

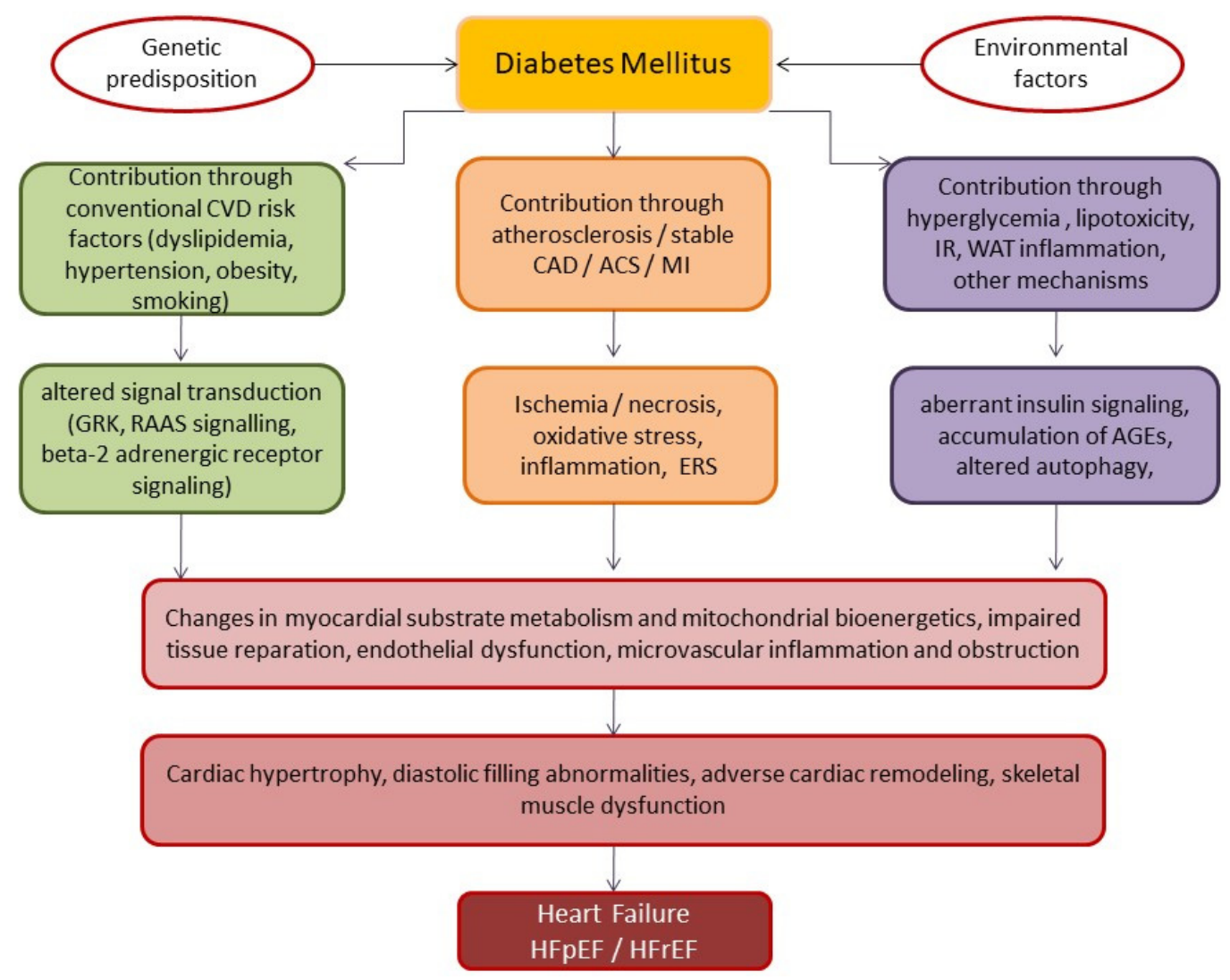

Figure 1. Underlying pathophysiological mechanisms contributing to the development of HF in patients with DM. Abbreviations: ACS, acute coronary syndrome; AGEs, advanced glycated endproducts; CAD, coronary artery disease; CVD, cardiovascular disease; GRK, g-protein receptor kinase; ERS, endoplasmic reticulum stress; MI, myocardial infarction; HF, heart failure; HFrEF, heart failure with reduced ejection fraction; HFpEF, heart failure with preserved ejection fraction; IR, insulin resistance; RAAS, renin-angiotensin-aldosterone system; WAT, white adipose tissue.

Of note, there is evidence that approximately one-third of patients with T2DM demonstrate isolated diastolic filling abnormality and subclinical myocardial dysfunction, unrelated to accelerating atherosclerosis or CVD [38]. Therefore, left ventricular (LV) diastolic 
dysfunction and LV concentric hypertrophy may be seen as the first signs of cardiac complications in patients with T2DM, independently from metabolic control [39,40]. In addition, uncontrolled T2DM with hyperglycemic status, hyperinsulinemia/insulin resistance, and lipotoxicity may result in cardiotoxicity, acute and chronic LV systolic dysfunction in the absence of CAD, valvular, congenital, or hypertensive heart disease, or alcoholism [41]. In fact, several phenotypes of T2DM-induced cardiac dysfunction may mostly relate to an overlap, but different alterations, which may be observed in failing hearts of T2DM patients. Indeed, substantial abnormalities in contractile (myosin, actin), regulatory (troponin, tropomyosin, and tropomodulin) and structural (predominantly titin, myomesin, and P-actinin) protein expression are responsible for the occurrence of diastolic and systolic dysfunctions as a primary myocardial alteration. For example, a decreased $\mathrm{Ca}^{2+}$ sensitivity along with a turnover of cardiac myosin heavy chain from V1 to V3 isoforms contributes to HFrEF [42]. Thus, an imbalance between adaptive and maladaptive molecular mechanisms of cardiac metabolism and reparation secures a link between T2DM and cardiac dysfunction [43-45]. MicroRNA and exosome-shaped transfer of active molecules are therefore also engaged in the pathogenesis of T2DM-induced cardiac dysfunction [46].

\section{Biomarkers in Diabetics with Known HF}

Biomarkers have been posed as promising surrogate indictors of pathologic changes in target organs (myocardium, kidney, vessels, and skeletal muscles) and metabolic homeostasis, particularly having diagnostic and predictive capabilities for patients with T2DM and HF [47]. Current clinical guidelines of the American College of Cardiology (ACC)/American Heart Association (AHA)/Heart Failure Society of America (HFSA) and European Cardiology Society (ESC) have proposed the use of biomarkers in personalized medical care of HF patients, regardless of T2DM, to diagnose HF and stratify patients at higher risk of poor prognosis, despite some differences in recommendations for practical use $[6,48,49]$. Table 1 reports the use of biomarkers in the management of HF according to 2016 ESC and 2017 ACC/AHA clinical guidelines [6,48].

Table 1. 2016 ESC and 2017 ACC/AHA/HFSA recommendations for the use of biomarkers in the management of HF.

\begin{tabular}{|c|c|c|c|c|c|c|c|}
\hline \multirow{2}{*}{ Strategy } & \multirow{2}{*}{ Biomarkers } & \multicolumn{3}{|c|}{ ESC, 2016} & \multicolumn{3}{|c|}{ ACC/AHA/HFSA, 2017} \\
\hline & & COR & LOE & Phenotype of HF & COR & LOE & Phenotype of HF \\
\hline Diagnosis & $\begin{array}{l}\text { BNP/NT-proBNP/MR- } \\
\text { proANP * }\end{array}$ & I & $\mathrm{A}$ & $\begin{array}{l}\text { AHF, HFpEF, } \\
\text { HFmrEF }\end{array}$ & I & $\mathrm{A}$ & $\mathrm{AHF}, \mathrm{CHF}$ \\
\hline \multirow{2}{*}{ Risk of in-hospital death } & BNP/NT-proBNP & I & $\mathrm{C}$ & $\mathrm{AHF}$ & I & $\mathrm{A}$ & AHF, CHF \\
\hline & hs-cTr & I & $\mathrm{C}$ & $\mathrm{AHF}$ & I & A & $\mathrm{AHF}, \mathrm{CHF}$ \\
\hline $\begin{array}{c}\text { Risk of recurrent } \\
\text { hospital admission }\end{array}$ & BNP/NT-proBNP & & & - & I & A & $\mathrm{AHF}, \mathrm{CHF}$ \\
\hline \multirow{4}{*}{$\begin{array}{c}\text { Risk of } \\
\text { post-discharged death }\end{array}$} & BNP/NT-proBNP & I & $\mathrm{A}$ & AHF, CHF & I & $\mathrm{A}$ & AHF, CHF \\
\hline & hs-cTr & I & $\mathrm{C}$ & $\mathrm{AHF}, \mathrm{CHF}$ & I & IIa & AHF, CHF \\
\hline & Galectin-3 & & & - & $\mathrm{IIlb}$ & $\mathrm{B}$ & $\mathrm{AHF}, \mathrm{CHF}$ \\
\hline & sST2 & & & - & $\mathrm{IIlb}$ & $\mathrm{B}$ & $\mathrm{AHF}, \mathrm{CHF}$ \\
\hline Prevention of HF onset & BNP/NT-proBNP & & & - & IIa & $\mathrm{B}$ & AHF, CHF \\
\hline Guided therapy & BNP/NT-proBNP & & & - & I & A & HFrEF/HFpEF \\
\hline
\end{tabular}

Abbreviations: ACC, American College of Cardiology; AHA, American Heart Association; BNP, B-type natriuretic peptide; HF, heart failure; HFSA, Heart Failure Society of America; NT-proBNP, N-terminal pro-B-type natriuretic peptide; sST2, soluble ST2; COR, class of recommendation; LOE, level of evidence; MR-proANP, mid-regional pro A-type natriuretic peptide; hs-cTn, high-sensitivity cardiac troponins; HFrEF, heart failure reduced ejection fraction; $\mathrm{HFpEF}$, heart failure preserved ejection fraction; HFmrEF, heart failure mid-range ejection fraction; *, provided for 2016 ESC recommendation only.

Although biomarkers of biomechanical stress (natriuretic peptides) and myocardial injury (high-sensitivity cardiac troponins (hs-cTn)), which are commonly used in HFrEF 
and to help to diagnose HFpEF, have high predictive utility in T2DM, they are markers of general pathological processes and consequently are not specific for T2DM-induced HF [50]. Conventional and alternative biomarkers of HF in T2DM patients are reported in Figure 2 .

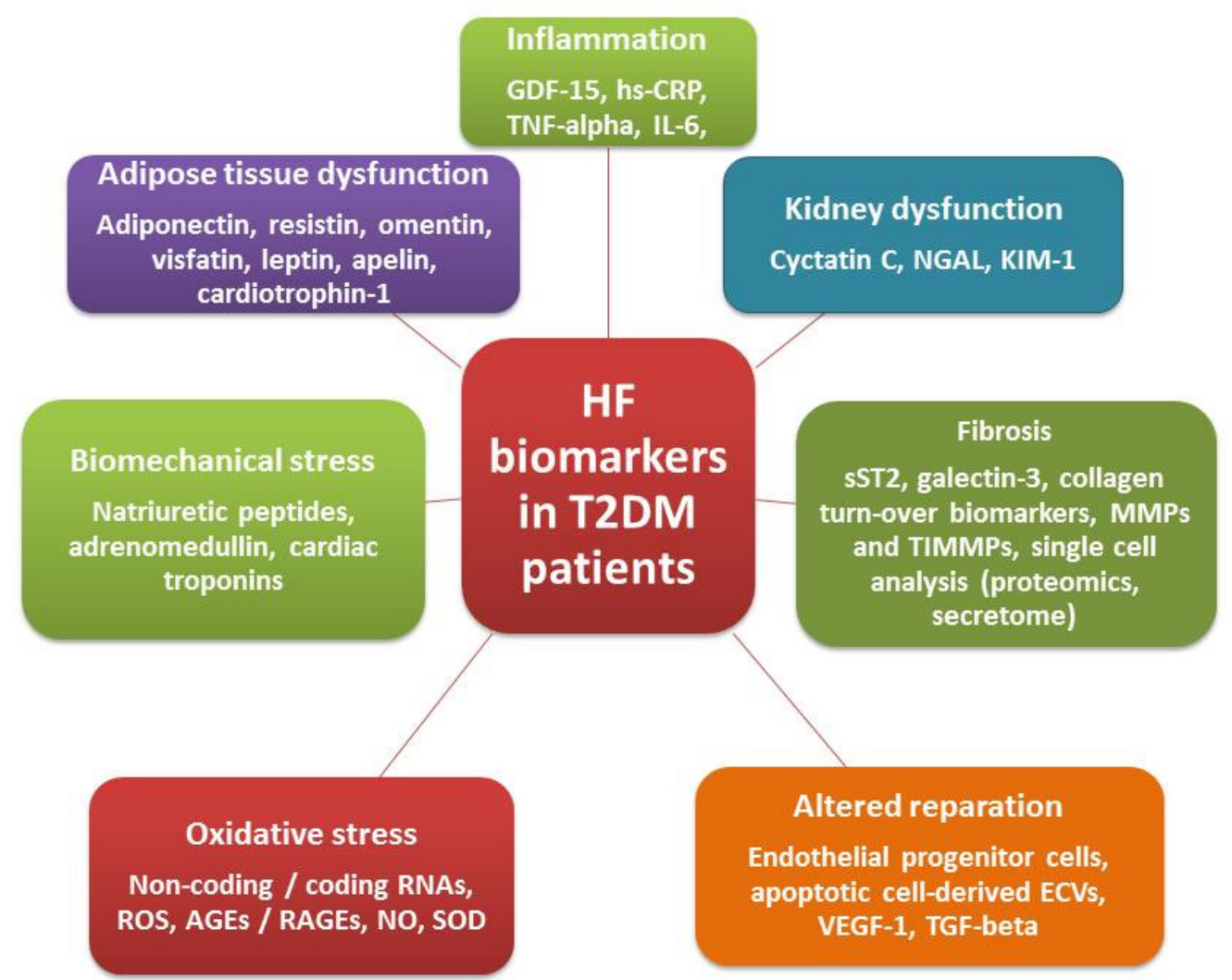

Figure 2. Conventional and alternative biomarkers of HF in T2DM patients. Abbreviations: hs-CRP, high-sensitivity C-reactive protein; IL, interleukin; GDF, growth differential factor; NO, nitric oxide; SOD, superoxide dismutase; RNA, ribonucleic acid; ECVs, extracellular vesicles; VEGF, vascular endothelial growth factor; MMP, matrix metalloproteinase; TNF, tumor necrosis factor; TIMMP, tissue inhibitor of MMP; TGF, transforming growth factor; ROC, reactive oxygen species; AGEs, advanced glycation end products, RAGEs, receptor for AGEs; NGAL, neutrophil gelatinase-associated lipocalin; KIM-1, kidney injury molecule-1.

Novel biomarkers of fibrosis and inflammation (soluble suppression of tumorigenicity2 (sST2) and galectin-3 (Gal-3)) are included in the ACC/AHA/HFSA HF guidelines as an alternative tool for CVD prediction and HF risk stratification, but their clinical utility in T2DM has not yet been proven and requires thorough elucidation. However, they were surrogate biomarkers for hard endpoints, such as all-cause and CV mortality and hospitalization in several large clinical trials in T2DM [51]. Other alternative HF biomarkers, such as oxidative stress, inflammation, and collagen turn-over biomarkers, have been investigated in the context of offering add-on information for prognoses and personalized risk management among patients with T2DM-induced HF [52-55]. Table 2 reports the advantages and disadvantages of HF biomarkers in patients with T2DM. 
Table 2. Advantages and disadvantages of HF biomarkers in T2DM patients.

\begin{tabular}{|c|c|c|c|c|}
\hline Biomarkers & $\begin{array}{c}\text { Underlying Pathophysiological } \\
\text { Mechanisms }\end{array}$ & $\begin{array}{l}\text { Possible Application } \\
\text { for HF Phenotype }\end{array}$ & Advantages & Disadvantages \\
\hline NPs & Biomechanical stress & HFrEF, HFpEF & $\begin{array}{l}\text { Available for diagnosis, risk } \\
\text { stratification, prognosis, and } \\
\text { point-to-care therapy }\end{array}$ & $\begin{array}{l}\text { High serum level variability, } \\
\text { variable cut-off points in } \\
\text { patients with } A F, C K D, A O, \\
\text { prediction in HFrEF is higher } \\
\text { than HFpEF }\end{array}$ \\
\hline hs-cTn & Myocardial injury & Manly HFrEF & $\begin{array}{c}\text { Available for risk } \\
\text { stratification and prognosis }\end{array}$ & No add-on prediction to NPs \\
\hline $\begin{array}{l}\text { Mid-regional-pro- } \\
\text { adrenomedullin }\end{array}$ & Neurohumoral activation & HFrEF, HFpEF & $\begin{array}{l}\text { Better than NPs in } \\
\text { predicting short-term } \\
\text { mortality in acute HF }\end{array}$ & $\begin{array}{l}\text { No superiority to NPs in } \\
\text { predictive ability among } \\
\text { chronic HFrEF/HFpEF }\end{array}$ \\
\hline hs-CRP, IL-6 & Inflammation & HFrEF, HFpEF & $\begin{array}{l}\text { Prediction of all-cause } \\
\text { mortality, CVD, } \\
\text { HF-related events }\end{array}$ & $\begin{array}{l}\text { Not suitable for point-of-care } \\
\text { therapy, no ability to increase } \\
\text { predictive ability of NPs, not } \\
\text { recommended by reputed } \\
\text { medical societies }\end{array}$ \\
\hline GDF-15 & Inflammation & HFrEF, HFpEF & $\begin{array}{l}\text { Available for improving } \\
\text { predictive ability of NPs, } \\
\text { suitable for multiple } \\
\text { biomarker strategy and } \\
\text { point-of-care therapy }\end{array}$ & $\begin{array}{l}\text { High cost, not recommended } \\
\text { by reputed medical societies }\end{array}$ \\
\hline sST2, galectin-3 & Fibrosis/inflammation & HFpEF & $\begin{array}{l}\text { Better than NPs for } \\
\text { predicting mortality and } \\
\text { HF-related events in non-HF } \\
\text { patients, low individual } \\
\text { serum level variability }\end{array}$ & High cost \\
\hline $\begin{array}{l}\text { Collagen turn-over } \\
\text { biomarkers }\end{array}$ & Fibrosis & HFpEF & $\begin{array}{l}\text { Available for risk } \\
\text { stratification and prognosis }\end{array}$ & $\begin{array}{l}\text { High cost, not recommended } \\
\text { by reputed medical societies }\end{array}$ \\
\hline
\end{tabular}

Abbreviations: AO, abdominal obesity; AF, atrial fibrillation; CKD, chronic kidney disease; NPs, natriuretic peptides; hs-CRP, highsensitivity C-reactive protein; sST2, soluble suppressor tumorigenisity-2; GDF-15, growth differential factor-15; IL, interleukin; HFrEF, heart failure with reduced ejection fraction; $\mathrm{HFpEF}$, heart failure with preserved ejection fraction.

\subsection{Biomechanical Stress Biomarkers}

\subsubsection{Natriuretic Peptides}

Natriuretic peptides (NPs) are released from cardiac myocytes as a result of myocardial stretching, volume overload, inflammation, and ischemia/hypoxic injury [56]. NPs are physiological antagonists of RAAS, and they protect against cardiovascular remodeling through the attenuation of water and sodium homeostasis, suppression of apoptosis, inflammation, and fibrosis, as well as the potentiation of vasodilation and vascular reparation, and attenuation of insulin resistance of the myocardium and skeletal muscles [57,58]. In addition, there is strong evidence regarding the protective capacity of NPs in tissue, which has translated to an improvement of clinical outcomes and decreased risk of HF admission [59].

HF development is associated with a marked increase in NP serum levels, which closely relates to a risk of CV death and HF admission [58]. Nevertheless, the improvements in clinical outcomes and prognoses in patients with HFrEF and HFpEF were strongly associated with lowering NP serum levels [60]. Being conventional biomarkers of biomechanical stress, NPs have been utilized as a diagnostic and predictive tool, predominantly for HF with reduced ejection fraction (HFrEF).

Although the role of NT-proBNP levels in predicting HF and CVD events in persons with prediabetes and T2DM is not yet well established, NPs improved the risk prediction of traditional risk factors for both incident HF and total CVD events in pre-diabetes or T2DM patients from ethnically diverse populations [61]. NPs exhibit optimistic results regarding prognostication of clinical outcomes directly related to HFrHF and HFpEF in diabetics treated with angiotensin receptor neprilysin inhibitor (ARNI), sodium-glucose cotransporter (SGLT)-2 inhibitors, and glucagon-like peptide (GLP)-1 agonists [62-65]. Indeed, 
NPs are substrates of neprilysin and thereby B-type of NP (BNP) concentrations rises with neprilysin inhibition, whereas NT-proBNP will continue to decrease with improvement in the functional class of HF $[66,67]$. At the same time, GLP-1 agonists were able to increase urinary sodium excretion and diuresis independent of NP changes [68]. Moreover, the EXAMINE (Examination of Cardiovascular Outcomes with Alogliptin versus Standard of Care) trial has shown that T2DM patients with persistently high levels of serum NTproBNP or an increase in NT-proBNP levels over 6 months while taking GLP-1 agonists or dipeptidyl peptidase 4 (DPP-4) inhibitors were at a significantly higher risk of CV mortality and HF occurrence when compared with those who had low levels of NT-proBNP at baseline or during the observation period [69]. SGLT-2 inhibitors have also demonstrated cardiac and renal protective effects in association with improving oxidative stress, LV diastolic filling, endothelial function, and decreasing BNP serum levels [70]. Thus, NPs are a powerful diagnostic and predictive tool for patients with T2DM with established HF and those at higher risk of HF occurrence using different phenotypes [71,72].

\subsubsection{Cardiac Troponins}

Progression of both T2DM and HF was independently associated with the development of subclinical myocardial damage, characterized by elevated levels of hs-cTn [73]. Metabolic and oxidative stress can damage cardiac myocyte membranes and may induce a leakage of cytoplasmic troponin through it [74]. Additionally, there is evidence of the occurrence of irreversible cardiac troponin modifications by shaping the complex with AGE [73]. These irreversible troponin and AGE complexes occur during myofilament relaxation and may play a key role in the development of contractility dysfunction [74].

Although circulating levels of hs-cTn are largely increased in HFpEF/HFrEF patients with T2DM, when compared to those without T2DM, hs-cTn yields additional prognostic information for HFrEF and HFpEF patients regardless of a presence of T2DM [75]. Moreover, hs-cTn predicts adverse outcomes independently from NT-proBNP and thereby can identify T2DM patients at an extremely high absolute CVD risk [76].

Importantly, $\mathrm{TnI}$ is commonly elevated among T2DM patients at higher risk of CVD events, incident HF, and stroke [77]. Circulating levels of hs-cTn in T2DM patients with atherosclerotic CVD were associated with higher hemoglobin A1c levels, severity of hypoglycemia, and markedly predicted subclinical changes in structure and function of the heart, brain, vasculature, and kidney [77,78]. In a meta-analysis of 28 relevant studies by Willeit P. et al. (2017) [79], it was unveiled that those in the general population with high hs-cTn concentrations within the normal range were associated with an increased risk of CVD. The ARIC (Atherosclerosis Risk in Communities) study has shown that elevated hs-TnI ( $\geq 3.8 \mathrm{ng} / \mathrm{L})$ in the general population is associated with greater incident CHD (hazard ratio $(\mathrm{HR})=2.20 ; 95 \% \mathrm{CI}, 1.64-2.95)$, ischemic stroke (HR $=2.99 ; 95 \% \mathrm{CI}, 2.01-4.46)$, atherosclerotic CVD (HR $=2.36$; 95\% CI, 1.86-3.00), HF hospitalization (HR, 4.20; 95\% CI, 3.28-5.37), and all-cause mortality (HR, 1.83; 95\% CI, 1.56-2.14) [80]. Overall, T2DM patients having HF with evidence of subclinical myocardial damage are at the highest risk for premature death, CVD, and HF-related events. However, mild elevated hs-cTn did not improve the predictive ability of NPs, and helps to rule out atherothrombotic events rather than HF progression in diabetics. However, hs-cTn did not fit to point-of-care therapy of $\mathrm{HF}$ and there is no need in continuous monitoring of the concentration in HF outpatients and ambulatory asymptomatic individuals at high risk of HF.

\subsubsection{Adrenomedullin}

Mid-regional pro-atrial natriuretic peptide (MR-proADM) is a C-terminal inactive fragment of adrenomedullin, which mediates vasodilatory and natriuretic properties [81]. Being elevated in acute HF and severe chronic HF, mostly in HFrEF, it has been found to have potential diagnostic and prognostic utility, although the findings obtained in clinical trials were controversial $[82,83]$. The BACH (Biomarkers in Acute Heart Failure) trial has shown that MR-proADM is superior to both BNP and NT-proBNP in predicting short- 
term mortality [83]. Serum levels of mid-regional pro-adrenomedullin (MR-proADM) were associated with 1-year CV events and all-cause mortality in patients with overt HF [84]. However, Vazquez-Montes MDLA et al. (2020) [85] reported that MR-proADM was not superior to NT-proBNP in the prediction of chronic HF. In a recently published meta-analysis comparing the diagnostic value of novel biomarkers for HF, Huang Z. et al. (2020) [86] revealed that MR-proADM had a poor discriminative value to confirm or exclude HF. Whether a serial measurement of MR-proADM is able to reclassify a risk of death due to $\mathrm{HF}$ individually depending on the presence of other $\mathrm{CV}$ risk factors including T2DM is not yet fully understood, because no correlation between T2DM and levels of MRproADM has been found for mortality or HF hospitalization [87]. Perhaps the evaluation of MR-proADM levels may be important for T2DM patients with abdominal obesity because these individuals exhibit an NP deficiency in early stages of HF, and other biomarkers can be used for the diagnosis and risk stratification of HF [88]. However, uncertainty in the total cost of biomarker implementation does not allow clearly proposing MR-proADM in the strategy of HF care.

\subsection{Biomarkers of Inflammation and Fibrosis}

Inflammatory biomarkers and biomarkers of fibrosis are not commonly used in routine clinical practice, but their evaluation in diabetics with HFrEF and HFpEF should be considered. The most important biomarkers having a certain predictive value are growth differential factor-15 (GDF-15), high-sensitivity C-reactive protein (hs-CRP), soluble suppressor tumorigenicity-2 (sST2), galectin-3 and interleukin-6 family cytokines.

\subsubsection{Growth Differential Factor-15}

Growth differential factor-15 (GDF-15) is a stress-induced multifactorial cytokine, which is markedly expressed in cardiac myocytes, endothelial cells, vascular smooth muscle cells, adipocytes, macrophages, and in normal and pathological conditions including HFpEF/HFrEF and T2DM [89]. The main biological function of GDF-15 is to improve glucose metabolism, attenuate energy homoeostasis and weight loss, as well as to protect various tissues, such as the myocardium, the vasculature, and the adipose tissue against injury by the inhibition of JNK, Bcl-2-associated death promoter (Bad), and epidermal growth factor receptor (EGFR) and activating Smad/eNOS, PI3K/AKT signaling pathways [89].

The XENDOS (XENical in the prevention of Diabetes in Obese subjects) trial has shown that the levels of GDF-15 are related to body weight, BMI, waist-to-hip ratio, and insulin resistance in non-T2DM obese individuals [90]. The elevation of circulating levels of GDF-15 strongly predicted the development of T2DM and HF and was associated with an adverse prognosis for both diseases [91]. Using a database derived from 3792 participants from the ARIC (Atherosclerosis Risk in Communities) Study, Echouffo-Tcheugui JB et al. (2021) [92] concluded that higher GDF-15 levels (highest vs. lowest quartile) were positively associated with T2DM (adjusted odds ratio $(\mathrm{aOR})=2.48,95 \% \mathrm{CI}=1.89,3.26)$, atherosclerotic $\mathrm{CVD}(\mathrm{aOR}=1.57,95 \% \mathrm{CI}=1.16,2.11)$, increased hs-cTnT $(\mathrm{aOR}=2.27,95 \% \mathrm{CI}=1.54,3.34)$, increased NT-proBNP $(\mathrm{aOR}=1.98,95 \% \mathrm{CI}=1.46,2.70)$, and $\mathrm{HF}(\mathrm{aOR}=3.22,95 \% \mathrm{CI}: 2.13$, 4.85). Importantly, GDF-15 added prognostic information to NYHA functional class, LVEF, and serum levels of NT-proBNP in patients with HF, regardless of age, body mass index, HF etiology, concomitant medical therapy, and renal function [93]. Although elevated serum levels of GDF-15 are closely related to mortality rate and the risk of HF occurrence, the exact mechanism of the interrelationship remains uncertain [94]. The prognostic utility of GDF-15 requires further evaluation in large clinical trials in a head-to-head comparison with traditional biomarkers.

\subsubsection{High-Sensitivity C-Reactive Protein}

Belonging to the superfamily of pentraxins, $\mathrm{C}$-reactive protein $(\mathrm{CRP})$ is a protein of acute systemic inflammation [95]. CRP as a biomarker is useful in identifying CVD risk 
when it is measured with highly sensitive assays, even in substantially low concentrations (now known as high-sensitivity CRP (hs-CRP) [96].

Serum levels of hs-CRP have been found to be independently predictive for the development of T2DM and CV disease in the general population [97,98]. T2DM was associated with elevated levels of hs-CRP and other indicators of diabetes-related CV risk, such as homeostatic model assessment, the levels of intact proinsulin and insulin, BMI, and beta-cell dysfunction, but not with fasting glucose [99,100]. However, Aryan Z. et al. (2018) [101], in a population-based study, showed that hs-CRP predicted CV complications including HF and diabetic kidney disease in patients with overt T2DM [101]. Moreover, they found that hs-CRP significantly improved the discriminative capacity of conventional CV risk scores when added to it [101]. In patients with established atherosclerotic CVD, elevated levels of hs-CRP were associated with poor clinical outcomes, especially among non-T2DM patients [102,103]. Additionally, Yang QQ et al. (2020) [104] presented evidence for a positive association between the levels of hs-CRP and the severity of major depression. A reduction in hs-CRP levels during the therapy of dyslipidemia or CAD has been shown to be closely related to an improvement in long-term prognosis [105]. Finally, in HFpEF, high hs-CRP levels were associated with greater comorbidity burden, including T2DM and abdominal obesity, even though almost $40 \%$ of HFpEF patients had normal values of hs-CRP [106]. In contrast, the levels of hs-CRP in HFrEF patients were higher when compared to those with $\mathrm{HFpEF}$, and it predicted myocardial dysfunction and HFrEF after acute myocardial infarction [107,108]. Surprisingly, a decrease in hs-CRP levels in acute HF was associated with a significant reduction in the 3-year risk of death in HFpEF patients, but not in HFrHF [109]. In conclusion, although the association of hs-CRP with clinical events has been found to be an independent predictor of CV morbidity and mortality [110], there is sufficient uncertainty in the predictive ability of hs-CRP in patients with different phenotypes of $\mathrm{HF}$ and consequently a high heterogeneity in $\mathrm{CV}$ risk factors present.

\subsubsection{Soluble Suppression of Tumorigenicity-2}

Soluble suppression of tumorigenicity-2 (sST2) is an established biomarker of inflammation and fibrosis, having certain predictive potency [111]. ST2 interferes with interleukin-33 and thereby induces the up-regulated expression of the transmembrane isoform ST2 ligand on the surfaces of target cells, resulting in biomechanical myocardial stress, injury, and inflammation. Finally, sST2 exerts protective effects on the myocardium by suppressing fibrosis and attenuating hypertrophy, thus enhancing survival.

Among inflammatory biomarkers, sST2 has been approved by the experts from the ACC / AHA/HFSA for risk stratification of patients with HF, because it has demonstrated high accuracy and reproducibility in serial measures at a reasonable cost and adds predictive value to NPs and cardiac troponins for HF [112]. In addition, sST2 demonstrates a high discriminative ability for predicting $\mathrm{CV}$ morbidity and mortality, HF occurrence and hospitalization independently from common $\mathrm{CV}$, and metabolic comorbidities, such as diabetic kidney disease, renal dysfunction, and hypertension [113-116]. sST2 can also stratify the patients with HFrEF at higher risk of sudden death [113]. Furthermore, elevated levels of sST2 provide additional prognostic information for different phenotypes of HF, exceeding the ability of NT-proBNP $[117,118]$. Thus, sST2 appears to be a powerful predictor for clinical outcomes in HF patients, regardless of the presence of T2DM, while high economic burden is considered as the main constraint for an implementation of single and serial sST2 measures in routine clinical practice [117].

\subsubsection{Galectin-3}

Galectin-3 is a $\beta$-galactosidase-binding lectin, which belongs to the galectin family [119]. Its biological functions include the modulation of cell growth, proliferation, differentiation, suppression of apoptosis, pre-mRNA splicing, attenuation of angiogenesis, reduction in inflammation, and fibrosis [120-122]. It has been established that a deficiency of galectin-3 mediates tissue injury, whereas the over-expression of galectin-3 was asso- 
ciated with tissue protection [123]. In addition, galectin-3 serves as a prognostic cardiac biomarker with promising therapeutic potency [123].

The Dallas Heart Study showed that levels of galectin-3 were associated with T2DM prevalence, incident T2DM, and fat compartments [124]. In addition, galectin-3 levels were positively correlated with levels of hs-CRP, IL-18, monocyte chemoattractant protein 1, soluble TNF receptor 1A, myeloperoxidase, C-peptide, and homeostatic model assessment for insulin resistance [124]. Moreover, serum galectin-3 is independently related to progressive renal disease in T2DM, CVD and increased risk of all-cause mortality [125,126].

Serum levels of galectin-3 have been shown to increase in HF patients, and were associated with myocardial fibrosis, adverse cardiac remodeling, atrial fibrillation, and CAD $[127,128]$. Furthermore, galectin-3 is considered not only as a powerful predictive biomarker of incident HF, but also as a mediator of T2DM progression $[129,130]$. Among HFpEF patients, the levels of galectin-3 were significantly positively associated with age, creatinine clearance, arterial stiffness (determined by the measurement of carotid femoral pulse wave velocity), aldosterone and BNP levels, and inversely correlated with LV ejection fraction [131-133]. Among 1386 patients with a $\geq 1$ risk factor for HF (e.g., hypertension, T2DM, and atherosclerotic CVD) or previously suspected HF, that were enrolled in the DIAST-CHF study, galectin- 3 levels of $>313.57 \mathrm{ng} / \mathrm{mL}$ (sensitivity $=0.61$ and specificity $=0.73$ ) predicted incident $\mathrm{HFpEF}$, adjusted all-cause mortality, and the adjusted composite of CV hospitalization and death [134]. Gocer H. et al. (2019) [135] concluded that galectin-3 concentrations were positively associated with HF severity and negatively correlated with left ventricular ejection fraction.

Elevated levels of galectin-3 substantially predicted mortality in acute HF, as well as in both phenotypes of chronic HF [136]. Although recent investigations found that galectin-3 was not superior to NT-proBNP, sST2, GDF-15, and hs-CRP as a predictor of mortality, the combination of galectin-3 and NPs had better discriminative capacity for predicting mortality when compared with either of the biomarkers alone [137,138]. Overall, galectin-3 has shown the ability to predict HF regardless of T2DM beyond the conventional biomarkers, such as NPs and cardiac troponins, but its role in the point-of-care of HF patients still needs investigation and future studies.

\subsubsection{Interleukin-6 Family Cytokines}

The interleukin (IL)-6 family is a heterogenic group of cytokines, consisting of IL-6, IL-11, cardiotrophin 1 (CT-1), cardiotrophin-like cytokine (CLC), ciliary neurotrophic factor (CNTF), leukemia inhibitory factor (LIF), oncostatin M (OSM), and IL-27 [139]. These cytokines are engaged in metabolic and immune regulation, cardiac repair, and tissue protection [140,141]. The development of both T2DM and HF is associated with high variability in the oxidative stress-dependent activation of eNOS, which is regulated by IL-6 family cytokines. While these findings have hypothetical value, recently, SGLT2 inhibitors have been shown to have a favorable effect on $\mathrm{CV}$ outcomes in $\mathrm{HFrEF} / \mathrm{HFpEF}$, regardless of T2DM presence in connection with the reduction in inflammatory and oxidative stress and improvement of the NO-sGC-cGMP cascade and protein kinase $\mathrm{G}$ type $\mathrm{I} \alpha$ (PKGI $\alpha$ ) activity [142-144]. Whether CT-1 and other IL-6- family cytokines can be used as future biomarkers to monitor prospective effects of SGLT2 inhibitors on clinical course of HF and T2DM at higher risk for HF is not fully clear and needs further thorough evaluation in large clinical trials.

\subsubsection{Other Biomarkers of Fibrosis}

Novel biomarkers (matrix metalloproteinases (MMPs) and tissue inhibitors of MMP (TIMP), collagen degradation products) have been discussed considerably in the context of risk stratification in T2DM with HF but have not yet been tested directly in large clinical trials. Therefore, the clinical perspectives of these biomarkers are not yet known [13]. Despite serious concerns regarding the essential ability of these circulating biomarkers to reflect both quantitative and qualitative morphological changes in the cardiac extracellular matrix, 
there is a large body of evidence drawn from preclinical and clinical studies that suggests a promising role of collagen turn-over biomarkers in the development of adverse cardiac remodeling and HF [145]. The potential of T2DM to lead primarily to the development of HFpEF depends on impaired collagen homeostasis and cardiac fibrosis. Indeed, there is a disproportion in the circulating levels of collagen synthesis biomarkers (procollagen type I N-terminal propeptide (PINP), procollagen type III N-terminal propeptide (PIIINP), and biomarkers of collagen degradation (c-terminal telopeptide of collagen type I (CTx)) among HF patients with left ventricular ejection fraction $<50 \%$. In fact, circulating levels of these biomarkers were positively correlated with the severity of $\mathrm{HF}$, which was confirmed by NT-proBNP, E/E', and left atrial volume [146]. Moreover, elevated circulating levels of procollagen I N-terminal peptide (PINP) and procollagen III N-terminal peptide (PIIINP), MMP-1, MMP-3, MMP-9, and TIMP-1 were associated with higher rates of CV mortality and HF hospitalization in patients with overt HFrEF and HFmrEF [147,148]. Surprisingly, long-term prognosis of HF outpatients was comparable, regardless of whether patients had HFpEF or HFrEF [149]. In contrast, the MESA (Multi-Ethnic Study of Atherosclerosis) trial showed that high levels of circulating ICTP and PIIINP were solely associated with incident HFpEF, but not HFrEF [150]. However, Ferreira JP et al. (2019) [151] reported that collagen Lysyl oxidase-like 2 (Lox12), which is up-regulated in the cardiac interstitium in $\mathrm{HF}$, was found to be a powerful trigger for cardiac fibroblasts via PI3K/AKT to express TGF- $\beta 2$, promoting the fibroblast-to-myofibroblast transformation. Moreover, LOXL2 concentrations were elevated in the serum of HF patients and positively correlated with BNP and NT-proBNP [151]. Overall, biomarkers of collagen homeostasis transformation could be strongly linked to inflammation, apoptosis, vascular function, extracellular matrix remodeling, blood pressure control, and energy metabolism, and therefore did not have high specificity for HF development or progression [152]. When added to conventional biomarkers, such as BNP, NT-pro-BNP, and sST2, circulating biomarkers reflecting excessive myocardial collagen type-I cross-linking and extracellular matrix remodeling were able to substantially increase the predictive ability of the entire model, especially in HFpEF patients with T2DM, atrial fibrillation, or hypertension [153,154].

\section{Multiple Biomarker Strategies}

Multiple biomarker predictive models are considered as an effective method to increase the specificity and sensitivity of a single biomarker tool [155]. Data confirm the superiority of multiple models compared with conventional models in risk stratification in HFpEF, whereas the adoption of serial biomarker measurements for risk stratification in HFpEF remains uncertain. However, different combinations of circulating cardiac biomarkers are likely a promising tool to improve prediction, risk stratification, and therapy in T2DM with HF, although there are limited data on the optimal number of biomarkers that can be allocated to improve point-of-care therapy among both HFrEF and HFpEF patients [156]. There is no strong evidence that single biomarker use is superior to a multiple biomarker strategy for every clinical condition in HF patients. For instance, the MOLITOR (Impact of Therapy Optimisation on the Level of Biomarkers in Patients with Acute and Decompensated Chronic Heart Failure) study has shown that serial measurements of multiple biomarkers (C-terminal fragment of pre-pro-vasopressin, NT-proBNP, midregional pro-atrial natriuretic peptide, mid-regional pro-adrenomedullin, and C-terminal pro-endothelin-1) in advanced HF were no better than measurements of the C-terminal fragment of pre-pro-vasopressin [157]. Pandey A. et al. (2021) [158] evaluated the application of a biomarker-based risk score to identify patients with dysglycemia that were at high risk of incident HF. They enrolled individuals from three cohort studies (ARIC (Atherosclerosis Risk In Communities), DHS (Dallas Heart Study), and MESA (MultiEthnic Study of Atherosclerosis)). The original biomarker score included hs-cTnT $\geq 6 \mathrm{ng} / \mathrm{L}$, NT-proBNP $\geq 125 \mathrm{pg} / \mathrm{mL}$, hs-CRP $\geq 3 \mathrm{mg} / \mathrm{L}$, and left ventricular hypertrophy identified by electrocardiography with one point for each abnormal parameter. The authors found that the 5-year risk for HF was associated with an increase in biomarker score; moreover, 
the highest risk was noted in patients with total scores of $\geq 3$ (diabetes: $12.0 \%$; pre-diabetes: $7.8 \%$ ). Thus, it has been established that the biomarker score can stratify the HF risk among patients with T2DM and pre-diabetes. Berezin AE et al. (2019) [159] reported that the combination of NT-proBNP and ST2 had higher prognostic ability when compared with each biomarker alone in patients with acute HF, except for galectin- 3 and hs-CRP, which did not increase in discriminative potency when compared to a multiple biomarker model in ischemia-induced HF. Consequently, these conflicting results deserve closer investigation in large clinical trials in the future.

\section{Point-of-Care Clinical Diagnostics in HF}

In the clinical setting, the detection of individual biomarkers or a combined analysis thereof are promising tools to support the manifestation and diagnosis of cardiac diseases, such as HF. The ACC/ Aha/HFSA guidelines (2017) [6] have also recommended the measurement of additional biomarkers, such as sST-2 and galectin-3, for the risk assessment in HF. Although multiple assays are available to detect a vast number of biomarkers, they are most often rather expensive and time-consuming. For instance, as far as most enzymelinked immunosorbent assays (ELISA) are concerned, several hours or one entire day are necessary to obtain the assay results, depending on the kit used. However, in point-of-care clinical diagnostics, it is crucial to obtain reliable results within a short time range. Multiple companies have addressed this challenge and have already successfully rolled out some rapid tests for biomarker analysis.

\subsection{Natriuretic Peptides}

As mentioned above, NPs are released into sera as a consequence of myocardial stress, such as stretching, overload, inflammation, or ischemia. Therefore, these peptides constitute important biomarkers for risk assessment in HF and are already in clinical application [60]. Originally, there were at least four rapid tests for the quantification of BNP available: (1) The Biosite Triage BNP (Biosite Diagnostics, San Diego, CA, USA) has been widely used in several clinical trials as an approved BNP rapid assay for bedside testing $[160,161]$. This assay is based on a fluorescence immunoanalysis signal detection which is directly dependent on the amount of BNP in plasma. Quantitative results are gained within 15 min after sampling [161]; (2) The second assay is based on an electrochemiluminescent procedure that detects NT-proBNP which may be obtained within 18 min by a Roche Cobas analyzer (Roche Diagnostics, Indianapolis, IN, USA) [162]; (3) The DVIA Centaur BNP ${ }^{\circledR}$ assay by Bayer Healthcare LLC (Tarrytown, NY, USA) [163]; and the (4) AxSYM ${ }^{\circledR}$ BNP assay by Abbott Diagnostics (Abbott Park, IL, USA) [164] also have found wide application in several studies [165]. Several more rapid kits have been rolled out, mainly manufactured by Alere, Roche, Quidel and pts Diagnostics [166].

\subsection{Cardiac Troponins}

Besides BNP, cardiac troponin is an important biomarker for cardiovascular events, in particular, cardiac necrosis. The current guidelines for HF recommend the evaluation of cardiac troponin in patients with HFpEF as well as HFrEF. The evaluation of cTn levels is intended to be used for the prognosis prediction in HF. More than 20 years ago, the first rapid tests for the fast detection of cardiac troponin were developed [167]. Since then, several more tests have been established to facilitate their use as bedside tests, such as Spectral Cardiac STATus Troponin I Rapid Test (Spectrum Diagnostics, Cairo, Egypt) [168], Nadal troponin I cassette (Nal Von Minden, Regensburg, Germany), Hexagon Troponin (Human Diagnostics, Wiesbaden, Germany), Troponitest+ (All Diag, Strasbourg, France), and Amicheck-Trop (Zephir Biomedicals, Goa, India) [169]. Nowadays, there are more advanced bedside tests for the detection of cardiac biomarkers available that enable the simultaneous analysis of more than one protein of interest. For instance, H-FABP and cTnI Combo Rapid Test Cassette by BioZEK B.V. (Apeldoorn, the Netherlands) combines the detection of heart-type fatty acid protein (h-FABP), an MI and ischemia marker, with 
troponin I in a single test cassette. Although several companies provide cTNI assays, Roche Diagnostics (Indianapolis, IN, USA) has the monopoly for cTNT assays [170].

\subsection{Adrenomodullin}

Adrenomodullin belongs to the family of peptide hormones and consists of 52 amino acids with a C-terminal fragment and a ring structure [171]. People without health impairments have low ADM levels in their plasma. Several studies have investigated high levels of adrenomodullin in humans with HF and found a correlation with worse longterm prognosis [172,173]. The clinical use of this biomarker is limited due to the potential inconsistency of the laboratory tests. For the achievement of satisfying results, a lot of material, incubation time, and preanalytical sample extraction is necessary. Midregional pro-adrenomodullin was discovered as an alternative option for reliable results [174-176].

A novel sandwich immunoassay has been used (BRAHMS MR-proADM; BRAHMS Aktiengesellschaft, Heningsdorf, Berlin, Germany) since MR-proADM was discovered. Analytical detection with this assay is limited to $0.08 \mathrm{nmol} / \mathrm{L}$. For values $>0.12 \mathrm{nmol} / \mathrm{L}$, the inter-assay coefficient of variance is $<20 \%$ [176].

\subsection{GDF-15}

GDF-15 shows clinical relevance because it is released into the circulation in several manifestations, such as CVD and HF [89]. Although GDF-15/MIC-1 Human ELISA from BioVendor Laboratory Medicine (Modrice, Czech Re-public) [177] is approved for clinical diagnostics, automated detection methods have emerged recently, e.g., electrochemiluminescence (Elecsys ${ }^{\circledR}$ ) immunoassay by Roche Diagnostics (Basel, Switzerland). It is based on a sandwich immunoassay that enables the detection of GDF-15 in a $35 \mu \mathrm{L}$ whole blood sample. It is a rapid and straightforward procedure with little personnel effort [178].

\section{5. hs-CRP}

C-reactive protein (CRP) is a well-researched marker of not only infectious and inflammatory conditions, but also cardiovascular illness [179]. It has been integrated into routine laboratory diagnostics in recent years. Several point-of-care testing devices for CRP are available. Concerning these, several studies were able to demonstrate a benefit in decisionmaking regarding antibiotic prescriptions in emergency departments [180,181]. For CVDs and risk factors, a benefit of point-of-care CRP diagnostics has been postulated [182,183]. However, evidence supporting routine clinical use is still scarce [184]. Further studies on the decision-making relevance of rapid CRP testing for CVDs are warranted.

\section{6. $S T-2$}

SST2 has gained major interest in cardiovascular research, and has emerged as a biomarker for hemodynamic stress, fibrosis, and inflammation [111]. However, it has not yet been established in widespread and routine clinical diagnostics. To date, only two assays have gained certificates for clinical usage: the highly sensitive ELISA kit Presage Assay [185,186], and the ASPECT PLUS ST2 Quantitative Rapid Test Assay [187], both manufactured by Critical Diagnostics (San Diego, CA, USA). Assay results of the latter are obtained within $20 \mathrm{~min}$; therefore, it may provide a promising tool in point-of-care clinical diagnostics [188].

\subsection{Galectin-3}

It is known that serum levels of galectin-3 increase as a consequence of several cardiovascular events, as mentioned above $[127,128]$. As far as HF is concerned, several clinical studies have addressed the prognostic properties of Gal-3 [119]. Most studies and clinical trials have used the BGM Galectin- $3^{\circledR}$ Test by BG Medicine Inc. (Foxboro, MA, USA) for the quantification of serum or plasma galectin-3 in HF patients $[189,190]$. Furthermore, some years later, automated assays such as ARCHITECT assay (Abbott Diagnostics, Abbott Park, IL, USA), based on chemiluminescent microparticle immunodetection, were introduced. It 
detects Gal-3 levels in serum or plasma within $29 \mathrm{~min}$ for the standard assay; the STATassay can be conducted in $18 \mathrm{~min}$ [191,192]. Gal-3 detection by VIDAS ${ }^{\circledR}$ Gal-3 assay (bioMerieux SA, Marcy-I'Etoile, France) uses enzyme-linked fluorescent signal detection [193]. A comparative study has unveiled that the Gal-3 levels measured by VIDAS ${ }^{\circledR}$ Gal-3 assay were comparable to those measured by ELISA. However, in contrast to the ELISA technique, VIDAS $^{\circledR}$ Gal-3 enables the detection of its concentration within 20 min [194]

\section{8. $I L-6$}

One of the most important biomarkers indicating inflammation is IL-6, which is also a highly prominent biomarker in HF [195]. Various detection methods have been established so far for the reliable and reproducible measurement of IL-6, such as ELISA, chemiluminescence immunoassays, magnetic colorimetric immunoassays, and a few more which were recently summarized by Huang et al. (2020) [196]. In the last few years, the need of IL-6 bedside tests for point-of-care (POC) medicine has emerged. Therefore, Milenia Biotec (Bad Nauheim, Germany) has developed a lateral flow-based immunoassay POC test, namely, Milenia QuickLine ${ }^{\circledR}$ IL-6. The analysis procedure was briefly described by Chaemsaithong et al. (2015) [197] and enables the semi-quantitative evaluation of IL-6 in serum, plasma, or cell culture supernatant after 20 min of incubation time [198].

\subsection{MMPs, TIMP and Collagen Degradation Products}

Matrix metalloproteinases (MMPs) and their tissue inhibitors (TIMPs) are responsible for maintenance of the equilibrium between collagen types I and II in the cardiac extracellular matrix. Certain causes of HF are the result of or are accompanied by changes in the cardiac extracellular structure, such as myocardial fibrosis in dilated cardiomyopathy $[199,200]$. Additionally, MMPs are an integral part of the atherosclerotic plaque extracellular matrix, and MMP plasma levels are elevated after myocardial infarction as a result of plaque rupture [201]. Thus, the MMP/TIMP system can be used as a possible target of HF treatment and possibly may serve as a future indicator of imminent myocardial infarction [202,203].

There are MMP-8-specific immunochromatographic dip-stick tests available, which can be used as a bedside test and deliver rapid information about MMP-8 activity. However, this activity can be a result of various pathologic conditions, such as periodontitis, peri-implantitis, and CVD [204,205]. Therefore, use as an early detection method of atherosclerotic plaque rupture cannot be proven yet. There are an abundance of point-ofcare collagen degradation assays, which could be useful in the early detection of cardiac remodeling. However, a relevant clinical use for this application is still to be discovered in the future [206].

\section{Conclusions}

We found that substantial heterogeneity of CV risk factors, including T2DM, hypertension, and atherosclerotic CVD in patients with $\mathrm{HFpEF}$, hinders accurate risk stratification and prediction. Thus, new biomarker-based approaches would sufficiently improve risk stratification and the prediction of poor clinical outcomes. Although current risk stratification strategies of HFrEF patients are based on the determination of NP levels, their normal concentrations do not exclude a diagnosis of HFpEF besides in diabetics. The combination of multiple biomarkers, such as NPs, sST2, and cardiac troponins, was predominantly observed as a powerful predictor of all-cause mortality and hospitalization in HFrEF, but this combined model may be prognostically important in symptomatic HFpEF. However, their role in T2DM patients with diastolic dysfunction and asymptomatic HFpEF remains uncertain. Novel biomarkers of inflammation (mid-regional pro adrenomedullin), fibrosis (galectin-3), inflammation (GDF-15), and collagen turn-over biomarkers have shown potential benefits in determining the prognosis in T2DM patients with concomitant HFpEF regardless of NPs, although their role in point-of-care and routine clinical practice needs elucidation in large clinical trials. Multiple biomarker models appear to be viable for the 
personalized, biomarker-oriented care of T2DM patients at high risk of HF and overt HF. However, the high costs for biomarker-guided administration remain the main constraint for implementation of this approach in routine clinical practice.

Funding: This research received no external funding.

Institutional Review Board Statement: Not applicable.

Informed Consent Statement: Not applicable.

Conflicts of Interest: The authors declare no conflict of interest.

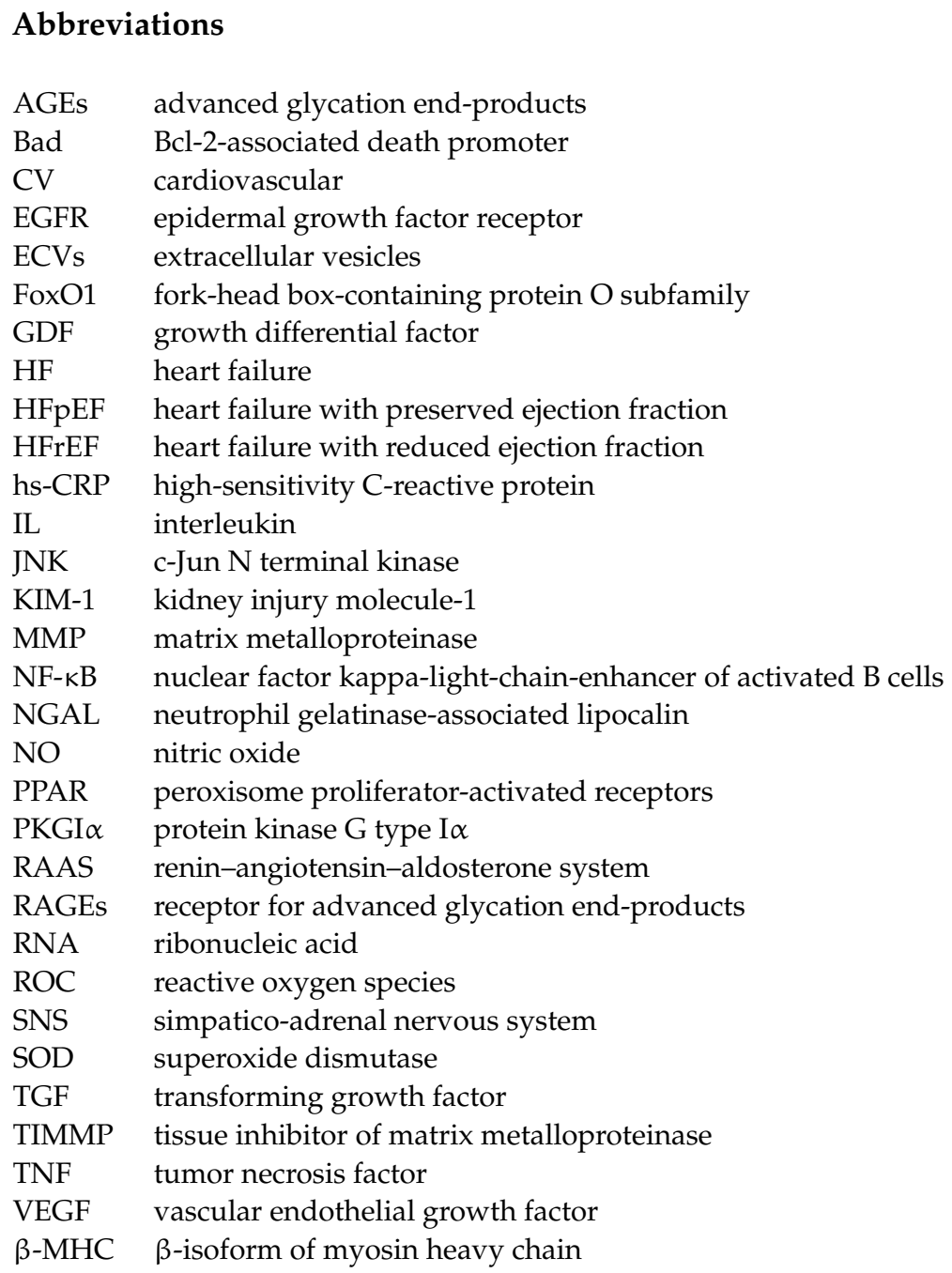

\section{References}

1. Cho, N.; Shaw, J.; Karuranga, S.; Huang, Y.; Fernandes, J.D.R.; Ohlrogge, A.; Malanda, B. IDF Diabetes Atlas: Global estimates of diabetes prevalence for 2017 and projections for 2045. Diabetes Res. Clin. Pract. 2018, 138, 271-281. [CrossRef] [PubMed]

2. Glovaci, D.; Fan, W.; Wong, N.D. Epidemiology of Diabetes Mellitus and Cardiovascular Disease. Curr. Cardiol. Rep. 2019, $21,21$. [CrossRef] [PubMed]

3. Ziaeian, B.; Fonarow, B.Z.G.C. Epidemiology and aetiology of heart failure. Nat. Rev. Cardiol. 2016, 13, 368-378. [CrossRef]

4. Lehrke, M.; Marx, N. Diabetes Mellitus and Heart Failure. Am. J. Cardiol. 2017, 120, S37-S47. [CrossRef] [PubMed]

5. Thrainsdottir, I.S.; Aspelund, T.; Thorgeirsson, G.; Gudnason, V.; Hardarson, T.; Malmberg, K.; Sigurdsson, G.; Rydén, L. The Association Between Glucose Abnormalities and Heart Failure in the Population-Based Reykjavik Study. Diabetes Care 2005, 28, 612-616. [CrossRef] 
6. Yancy, C.W.; Jessup, M.; Bozkurt, B.; Butler, J.; Casey, D.E., Jr.; Colvin, M.M.; Drazner, M.H.; Filippatos, G.S.; Fonarow, G.C.; Givertz, M.M.; et al. 2017 ACC/AHA/HFSA Focused Update of the 2013 ACCF/AHA Guideline for the Management of Heart Failure: A Report of the American College of Cardiology/American Heart Association Task Force on Clinical Practice Guidelines and the Heart Failure Society of America. Circulation 2017, 136, e137-e161. [CrossRef]

7. Kenny, H.C.; Abel, E.D. Heart Failure in Type 2 Diabetes Mellitus. Circ. Res. 2019, 124, 121-141. [CrossRef]

8. Berezin, A.E.; Berezin, A.A.; Lichtenauer, M. Emerging Role of Adipocyte Dysfunction in Inducing Heart Failure Among Obese Patients With Prediabetes and Known Diabetes Mellitus. Front. Cardiovasc. Med. 2020, 7, 583175. [CrossRef]

9. Kato, E.T.; Silverman, M.G.; Mosenzon, O.; Zelniker, T.A.; Cahn, A.; Furtado, R.H.M.; Kuder, J.; Murphy, S.A.; Bhatt, D.L.; Leiter, L.A.; et al. Effect of Dapagliflozin on Heart Failure and Mortality in Type 2 Diabetes Mellitus. Circulation 2019, 139, $2528-2536$. [CrossRef]

10. Thein, D.; Christiansen, M.N.; Mogensen, U.M.; Bundgaard, J.S.; Rørth, R.; Madelaire, C.; Fosbøl, E.L.; Schou, M.; Torp-Pedersen, C.; Gislason, G.; et al. Add-on therapy in metformin-treated patients with type 2 diabetes at moderate cardiovascular risk: A nationwide study. Cardiovasc. Diabetol. 2020, 19, 1-11. [CrossRef]

11. Lytvyn, Y.; Bjornstad, P.; Udell, J.A.; Lovshin, J.A.; Cherney, D.Z. Sodium Glucose Cotransporter-2 Inhibition in Heart Failure. Circulation 2017, 136, 1643-1658. [CrossRef] [PubMed]

12. Marsico, F.; Gargiulo, P.; Marra, A.M.; Parente, A.; Paolillo, S. Glucose Metabolism Abnormalities in Heart Failure Patients. Heart Fail. Clin. 2019, 15, 333-340. [CrossRef]

13. Berezin, A.E. Circulating Cardiac Biomarkers in Diabetes Mellitus: A New Dawn for Risk Stratification-A Narrative Review. Diabetes Ther. 2020, 11, 1271-1291. [CrossRef] [PubMed]

14. Lee, W.-S.; Kim, J. Diabetic cardiomyopathy: Where we are and where we are going. Korean J. Intern. Med. 2017, 32, 404-421. [CrossRef]

15. Udell, J.A.; Steg, P.G.; Scirica, B.M.; Eagle, K.; Ohman, E.M.; Goto, S.; Alsheikh-Ali, A.A.; Porath, A.; Corbalan, R.; UmezEronini, A.A.; et al. Metabolic syndrome, diabetes mellitus, or both and cardiovascular risk in outpatients with or at risk for atherothrombosis. Eur. J. Prev. Cardiol. 2014, 21, 1531-1540. [CrossRef] [PubMed]

16. Braunwald, E. Diabetes, heart failure, and renal dysfunction: The vicious circles. Prog. Cardiovasc. Dis. 2019, 62, 298-302. [CrossRef]

17. Cui, R.; Sun, S.Q.; Zhong, N.; Xu, M.X.; Cai, H.D.; Zhang, G.; Qu, S.; Sheng, H. The relationship between atherosclerosis and bone mineral density in patients with type 2 diabetes depends on vascular calcifications and sex. Osteoporos. Int. 2020, 31, 1135-1143. [CrossRef]

18. Dillmann, W.H. Diabetic Cardiomyopathy. Circ. Res. 2019, 124, 1160-1162. [CrossRef]

19. Kanamori, H.; Takemura, G.; Goto, K.; Tsujimoto, A.; Mikami, A.; Ogino, A.; Watanabe, T.; Morishita, K.; Okada, H.; Kawasaki, M.; et al. Autophagic adaptations in diabetic cardiomyopathy differ between type 1 and type 2 diabetes. Autophagy 2015, 11, 1146-1160. [CrossRef]

20. Li, S.; Liang, M.; Gao, D.; Su, Q.; Laher, I. Changes in Titin and Collagen Modulate Effects of Aerobic and Resistance Exercise on Diabetic Cardiac Function. J. Cardiovasc. Transl. Res. 2019, 12, 404-414. [CrossRef]

21. Hamdani, N.; Franssen, C.; Lourenço, A.; Falcão-Pires, I.; Fontoura, D.; Leite, S.; Plettig, L.; López, B.; Ottenheijm, C.A.; Becher, P.M.; et al. Myocardial Titin Hypophosphorylation Importantly Contributes to Heart Failure With Preserved Ejection Fraction in a Rat Metabolic Risk Model. Circ. Heart Fail. 2013, 6, 1239-1249. [CrossRef]

22. Feng, B.; Chen, S.; Chiu, J.; George, B.; Chakrabarti, S. Regulation of cardiomyocyte hypertrophy in diabetes at the transcriptional level. Am. J. Physiol. Metab. 2008, 294, E1119-E1126. [CrossRef]

23. Fender, A.C.; Pavic, G.; Drummond, G.R.; Dusting, G.J.; Ritchie, R.H. Unexpected anti-hypertrophic responses to low-level stimulation of protease-activated receptors in adult rat cardiomyocytes. Naunyn-Schmiedeberg's Arch. Pharmacol. 2014, 387, 1001-1007. [CrossRef] [PubMed]

24. Rosenkranz, A.C.; Hood, S.G.; Woods, R.L.; Dusting, G.J.; Ritchie, R.H. B-type natriuretic peptide prevents acute hypertrophic responses in the diabetic rat heart: Importance of cyclic GMP. Diabetes 2003, 52, 2389-2395. [CrossRef] [PubMed]

25. Sundgren, N.C.; Giraud, G.D.; Schultz, J.M.; Lasarev, M.R.; Stork, P.J.S.; Thornburg, K.L. Extracellular signal-regulated kinase and phosphoinositol-3 kinase mediate IGF-1 induced proliferation of fetal sheep cardiomyocytes. Am. J. Physiol. Integr. Comp. Physiol. 2003, 285, R1481-R1489. [CrossRef] [PubMed]

26. Mehrhof, F.B.; Müller, F.-U.; Bergmann, M.W.; Li, P.; Wang, Y.; Schmitz, W.; Dietz, R.; Von Harsdorf, R. In Cardiomyocyte Hypoxia, Insulin-Like Growth Factor-I-Induced Antiapoptotic Signaling Requires Phosphatidylinositol-3-OH-Kinase-Dependent and Mitogen-Activated Protein Kinase-Dependent Activation of the Transcription Factor cAMP Response Element-Binding Protein. Circulation 2001, 104, 2088-2094. [CrossRef] [PubMed]

27. Bando, Y.K.; Murohara, T. Diabetes-Related Heart Failure. Circ. J. 2014, 78, 576-583. [CrossRef] [PubMed]

28. Díez, J.; González, A.; Kovacic, J.C. Myocardial Interstitial Fibrosis in Nonischemic Heart Disease, Part 3/4. J. Am. Coll. Cardiol. 2020, 75, 2204-2218. [CrossRef]

29. Lam, C.S. Diabetic cardiomyopathy: An expression of stage B heart failure with preserved ejection fraction. Diabetes Vasc. Dis. Res. 2015, 12, 234-238. [CrossRef]

30. Passino, C.; Barison, A.; Vergaro, G.; Gabutti, A.; Borrelli, C.; Emdin, M.; Clerico, A. Markers of fibrosis, inflammation, and remodeling pathways in heart failure. Clin. Chim. Acta 2015, 443, 29-38. [CrossRef] 
31. González, A.; López, B.; Ravassa, S.; José, G.S.; Díez, J. The complex dynamics of myocardial interstitial fibrosis in heart failure. Focus on collagen cross-linking. Biochim. Biophys. Acta Bioenerg. 2019, 1866, 1421-1432. [CrossRef] [PubMed]

32. Berezin, A.E. Endogenous vascular repair system in cardiovascular disease: The role of endothelial progenitor cells. Australas. Med. J. 2019, 12, 42-48. [CrossRef]

33. Battiprolu, P.K.; Hojayev, B.; Jiang, N.; Wang, Z.V.; Luo, X.; Iglewski, M.; Shelton, J.M.; Gerard, R.D.; Rothermel, B.A.; Gillette, T.G.; et al. Metabolic stress-induced activation of FoxO1 triggers diabetic cardiomyopathy in mice. J. Clin. Investig. 2012, 122, 1109-1118. [CrossRef] [PubMed]

34. Qi, Y.; Zhu, Q.; Zhang, K.; Thomas, C.; Wu, Y.; Kumar, R.; Baker, K.M.; Xu, Z.; Chen, S.; Guo, S. Activation of Foxo1 by Insulin Resistance Promotes Cardiac Dysfunction and -Myosin Heavy Chain Gene Expression. Circ. Heart Fail. 2015, 8, 198-208. [CrossRef] [PubMed]

35. Liu, F.; Song, R.; Feng, Y.; Guo, J.; Chen, Y.; Zhang, Y.; Chen, T.; Wang, Y.; Huang, Y.; Li, C.-Y.; et al. Upregulation of MG53 Induces Diabetic Cardiomyopathy Through Transcriptional Activation of Peroxisome Proliferation-Activated Receptor $\alpha$. Circulation 2015, 131, 795-804. [CrossRef]

36. Wu, H.-K.; Zhang, Y.; Cao, C.-M.; Hu, X.; Fang, M.; Yao, Y.; Jin, L.; Chen, G.; Jiang, P.; Zhang, S.; et al. Glucose-Sensitive Myokine/Cardiokine MG53 Regulates Systemic Insulin Response and Metabolic Homeostasis. Circulation 2019, 139, 901-914. [CrossRef]

37. Bugger, H.; Abel, E.D. Molecular mechanisms of diabetic cardiomyopathy. Diabetologia 2014, 57, 660-671. [CrossRef]

38. Zarich, S.W.; Arbuckle, B.E.; Cohen, L.R.; Roberts, M.; Nesto, R.W. Diastolic abnormalities in young asymptomatic diabetic patients assessed by pulsed Doppler echocardiography. J. Am. Coll. Cardiol. 1988, 12, 114-120. [CrossRef]

39. Poirier, P.; Bogaty, P.; Philippon, F.; Garneau, C.; Fortin, C.; Dumesnil, J.-G. Preclinical diabetic cardiomyopathy: Relation of left ventricular diastolic dysfunction to cardiac autonomic neuropathy in men with uncomplicated well-controlled type 2 diabetes. Metabolism 2003, 52, 1056-1061. [CrossRef]

40. Ofstad, A.P.; Urheim, S.; Dalen, H.; Orvik, E.; Birkeland, K.I.; Gullestad, L.; Fagerland, M.W.; Johansen, O.E.; Aakhus, S. Identification of a definite diabetic cardiomyopathy in type 2 diabetes by comprehensive echocardiographic evaluation: A cross-sectional comparison with non-diabetic weight-matched controls. J. Diabetes 2015, 7, 779-790. [CrossRef]

41. Kocabaş, U.; Yılmaz, Ö.; Kurtoğlu, V. Diabetic cardiomyopathy: Acute and reversible left ventricular systolic dysfunction due to cardiotoxicity of hyperglycaemic hyperosmolar state-a case report. Eur. Heart J. Case Rep. 2019, 3, ytz049. [CrossRef] [PubMed]

42. Wold, L.E.; Ceylan-Isik, A.F.; Fang, C.X.; Yang, X.; Li, S.-Y.; Sreejayan, N.; Privratsky, J.R.; Ren, J. Metallothionein alleviates cardiac dysfunction in streptozotocin-induced diabetes: Role of Ca2+ cycling proteins, NADPH oxidase, poly (ADP-Ribose) polymerase and myosin heavy chain isozyme. Free Radic. Biol. Med. 2006, 40, 1419-1429. [CrossRef]

43. Jia, G.; Hill, M.A.; Sowers, J.R. Diabetic Cardiomyopathy. Circ. Res. 2018, 122, 624-638. [CrossRef] [PubMed]

44. Yu, X.; Deng, L.; Wang, D.; Li, N.; Chen, X.; Cheng, X.; Yuan, J.; Gao, X.; Liao, M.; Wang, M.; et al. Mechanism of TNF- $\alpha$ autocrine effects in hypoxic cardiomyocytes: Initiated by hypoxia inducible factor $1 \alpha$, presented by exosomes. J. Mol. Cell. Cardiol. 2012, 53, 848-857. [CrossRef] [PubMed]

45. Guo, C.A.; Guo, S. Insulin receptor substrate signaling controls cardiac energy metabolism and heart failure. J. Endocrinol. 2017, 233, R131-R143. [CrossRef] [PubMed]

46. Berezin, A.E.; Berezin, A.A. Extracellular Endothelial Cell-Derived Vesicles: Emerging Role in Cardiac and Vascular Remodeling in Heart Failure. Front. Cardiovasc. Med. 2020, 7, 47. [CrossRef]

47. Sarhene, M.; Wang, Y.; Wei, J.; Huang, Y.; Li, M.; Li, L.; Acheampong, E.; Zhengcan, Z.; Xiaoyan, Q.; Yunsheng, X.; et al. Biomarkers in heart failure: The past, current and future. Heart Fail. Rev. 2019, 24, 867-903. [CrossRef]

48. Ponikowski, P.; Voors, A.A.; Anker, S.D.; Bueno, H.; Cleland, J.G.F.; Coats, A.J.S.; Falk, V.; González-Juanatey, J.R.; Harjola, V.-P.; Jankowska, E.A.; et al. 2016 ESC Guidelines for the diagnosis and treatment of acute and chronic heart failure: The Task Force for the diagnosis and treatment of acute and chronic heart failure of the European Society of Cardiology (ESC). Developed with the special contribution of the Heart Failure Association (HFA) of the ESC. Eur. J. Heart Fail. 2016, 18, 891-975. [CrossRef]

49. Chow, S.L.; Maisel, A.S.; Anand, I.; Bozkurt, B.; De Boer, R.A.; Felker, G.M.; Fonarow, G.C.; Greenberg, B.; Januzzi, J.L.; Kiernan, M.S.; et al. Role of Biomarkers for the Prevention, Assessment, and Management of Heart Failure: A Scientific Statement From the American Heart Association. Circulation 2017, 135, e1054-e1091. [CrossRef]

50. Ibrahim, N.E.; Januzzi, J.L. Established and Emerging Roles of Biomarkers in Heart Failure. Circ. Res. 2018, 123, 614-629. [CrossRef]

51. Butler, J.; Packer, M.; Greene, S.J.; Fiuzat, M.; Anker, S.D.; Anstrom, K.J.; Carson, P.E.; Cooper, L.B.; Fonarow, G.C.; Hernandez, A.F.; et al. Heart Failure End Points in Cardiovascular Outcome Trials of Sodium Glucose Cotransporter 2 Inhibitors in Patients With Type 2 Diabetes Mellitus. Circulation 2019, 140, 2108-2118. [CrossRef] [PubMed]

52. Suthahar, N.; Meijers, W.C.; Brouwers, F.P.; Heerspink, H.J.; Gansevoort, R.T.; Van Der Harst, P.; Bakker, S.J.; De Boer, R.A. Heart failure and inflammation-related biomarkers as predictors of new-onset diabetes in the general population. Int. J. Cardiol. 2018, 250, 188-194. [CrossRef] [PubMed]

53. Wang, C.; Yang, H.; Gao, C. Potential biomarkers for heart failure. J. Cell. Physiol. 2019, 234, 9467-9474. [CrossRef]

54. Catalina, M.O.-S.; Redondo, P.C.; Granados, M.P.; Cantonero, C.; Sanchez-Collado, J.; Albarran, L.; Lopez, J.J. New Insights into Adipokines as Potential Biomarkers for Type-2 Diabetes Mellitus. Curr. Med. Chem. 2019, 26, 4119-4144. [CrossRef]

55. Berezin, A.E. Circulating Biomarkers in Heart Failure. Adv. Exp. Med. Biol. 2018, 1067, 89-108. [CrossRef] [PubMed] 
56. Correale, M.; On behalf of Master Program Students on Drug Development for Heart Failure; Monaco, I.; Brunetti, N.D.; Di Biase, M.; Metra, M.; Nodari, S.; Butler, J.; Gheorghiade, M. Redefining biomarkers in heart failure. Heart Fail. Rev. 2018, $23,237-253$. [CrossRef] [PubMed]

57. Potter, L.R.; Yoder, A.R.; Flora, D.R.; Antos, L.K.; Dickey, D.M. Natriuretic peptides: Their structures, receptors, physiologic functions and therapeutic applications. In Handbook of Experimental Pharmacology; Schmidt, H.H.H.W., Hofmann, F., Stasch, J.-P., Eds.; Springer: Berlin/Heidelberg, Germany, 2009; Volume 191, pp. 341-366, ISBN 9783540689607.

58. Goetze, J.P.; Bruneau, B.G.; Ramos, H.R.; Ogawa, T.; De Bold, M.K.; De Bold, A.J. Cardiac natriuretic peptides. Nat. Rev. Cardiol. 2020, 17, 698-717. [CrossRef]

59. Murphy, S.P.; Ibrahim, N.E.; Januzzi, J.L. Heart Failure with Reduced Ejection Fraction. JAMA 2020, 324, 488. [CrossRef] [PubMed]

60. Zile, M.R.; Claggett, B.L.; Prescott, M.F.; McMurray, J.J.; Packer, M.; Rouleau, J.L.; Swedberg, K.; Desai, A.S.; Gong, J.; Shi, V.C.; et al. Prognostic Implications of Changes in N-Terminal Pro-B-Type Natriuretic Peptide in Patients With Heart Failure. J. Am. Coll. Cardiol. 2016, 68, 2425-2436. [CrossRef]

61. Nguyen, K.; Fan, W.; Bertoni, A.; Budoff, M.J.; Defilippi, C.; Lombardo, D.; Maisel, A.; Szklo, M.; Wong, N.D. N-terminal Pro B-type Natriuretic Peptide and High-sensitivity Cardiac Troponin as Markers for Heart Failure and Cardiovascular Disease Risks According to Glucose Status (from the Multi-Ethnic Study of Atherosclerosis [MESA]). Am. J. Cardiol. 2020, 125, 1194-1201. [CrossRef]

62. Myhre, P.L.; Vaduganathan, M.; Claggett, B.; Packer, M.; Desai, A.S.; Rouleau, J.L.; Zile, M.R.; Swedberg, K.; Lefkowitz, M.; Shi, V.; et al. B-Type Natriuretic Peptide During Treatment With Sacubitril/Valsartan. J. Am. Coll. Cardiol. 2019, 73, 1264-1272. [CrossRef] [PubMed]

63. Chang, K.-W.; Fox, S.; Mojaver, S.; Maisel, A.S. Using biomarkers to guide heart failure management. Expert Rev. Cardiovasc. Ther. 2017, 15, 729-741. [CrossRef]

64. Nassif, M.E.; Windsor, S.L.; Tang, F.; Khariton, Y.; Husain, M.; Inzucchi, S.E.; McGuire, D.K.; Pitt, B.; Scirica, B.M.; Austin, B.; et al. Dapagliflozin Effects on Biomarkers, Symptoms, and Functional Status in Patients with Heart Failure With Reduced Ejection Fraction. Circulation 2019, 140, 1463-1476. [CrossRef] [PubMed]

65. Nielsen, R.; Jorsal, A.; Tougaard, R.S.; Rasmussen, J.J.; Schou, M.; Videbaek, L.; Gustafsson, I.; Faber, J.; Flyvbjerg, A.; Wiggers, H.; et al. The impact of the glucagon-like peptide-1 receptor agonist liraglutide on natriuretic peptides in heart failure patients with reduced ejection fraction with and without type 2 diabetes. Diabetes Obes. Metab. 2020, 22, 2141-2150. [CrossRef] [PubMed]

66. Moro, C. Targeting cardiac natriuretic peptides in the therapy of diabetes and obesity. Expert Opin. Ther. Targets 2016, 20, 1445-1452. [CrossRef]

67. Wolsk, E.; Claggett, B.; Pfeffer, M.A.; Diaz, R.; Dickstein, K.; Gerstein, H.C.; Lawson, F.C.; Lewis, E.F.; Maggioni, A.P.; McMurray, J.J.V.; et al. Role of B-Type Natriuretic Peptide and N-Terminal Prohormone BNP as Predictors of Cardiovascular Morbidity and Mortality in Patients With a Recent Coronary Event and Type 2 Diabetes Mellitus. J. Am. Heart Assoc. 2017, 6, e004743. [CrossRef]

68. Scheen, A.J. Cardiovascular Effects of New Oral Glucose-Lowering Agents. Circ. Res. 2018, 122, 1439-1459. [CrossRef]

69. Jarolim, P.; White, W.B.; Cannon, C.P.; Gao, Q.; Morrow, D.A. Serial Measurement of Natriuretic Peptides and Cardiovascular Outcomes in Patients With Type 2 Diabetes in the EXAMINE Trial. Diabetes Care 2018, 41, 1510-1515. [CrossRef]

70. Shyangdan, D.S.; Uthman, O.; Waugh, N. SGLT-2 receptor inhibitors for treating patients with type 2 diabetes mellitus: A systematic review and network meta-analysis. BMJ Open 2016, 6, e009417. [CrossRef]

71. Buckley, L.F.; Canada, J.M.; Del Buono, M.G.; Carbone, S.; Trankle, C.R.; Billingsley, H.; Kadariya, D.; Arena, R.; Van Tassell, B.W.; Abbate, A. Low NT-proBNP levels in overweight and obese patients do not rule out a diagnosis of heart failure with preserved ejection fraction. ESC Heart Fail. 2018, 5, 372-378. [CrossRef]

72. Martinsson, A.; Oest, P.; Wiborg, M.-B.; Reitan, Ö.; Smith, J.G. Longitudinal evaluation of ventricular ejection fraction and NT-proBNP across heart failure subgroups. Scand. Cardiovasc. J. 2018, 52, 205-210. [CrossRef] [PubMed]

73. Selvin, E.; Lazo, M.; Chen, Y.; Shen, L.; Rubin, J.; McEvoy, J.W.; Hoogeveen, R.C.; Sharrett, A.R.; Ballantyne, C.M.; Coresh, J. Diabetes Mellitus, Prediabetes, and Incidence of Subclinical Myocardial Damage. Circulation 2014, 130, 1374-1382. [CrossRef] [PubMed]

74. Van Bockel, E.A.; Tulleken, J.E.; Ligtenberg, J.J.; van der Werf, T.S.; Aarts, L.P.; Zijlstra, J.G. De betekenis van een verhoogde troponinewaarde zonder acute ischemische hartziekte [The significance of elevated troponin levels in the absence of acute cardiac ischaemia]. Ned. Tijdschr. Geneeskd. 2005, 149, 1879-1883.

75. Rørth, R.; Jhund, P.S.; Kristensen, S.L.; Desai, A.S.; Køber, L.; Rouleau, J.L.; Solomon, S.D.; Swedberg, K.; Zile, M.R.; Packer, M.; et al. The prognostic value of troponin $\mathrm{T}$ and $\mathrm{N}$-terminal pro B-type natriuretic peptide, alone and in combination, in heart failure patients with and without diabetes. Eur. J. Heart Fail. 2019, 21, 40-49. [CrossRef]

76. Ali, D.; Callan, N.; Ennis, S.; Powell, R.; McGuire, S.; McGregor, G.; OWeickert, M.; AMiller, M.; Cappuccio, F.P.; Banerjee, P. Heart failure with preserved ejection fraction (HFpEF) pathophysiology study (IDENTIFY-HF): Does increased arterial stiffness associate with $\mathrm{HFpEF}$, in addition to ageing and vascular effects of comorbidities? Rationale and design. BMJ Open 2019, 9, e027984.

77. Sharma, A.; Vaduganathan, M.; Ferreira, J.P.; Liu, Y.; Bakris, G.L.; Cannon, C.P.; White, W.B.; Zannad, F. Clinical and Biomarker Predictors of Expanded Heart Failure Outcomes in Patients With Type 2 Diabetes Mellitus After a Recent Acute Coronary Syndrome: Insights From the EXAMINE Trial. J. Am. Heart Assoc. 2020, 9, e012797. [CrossRef] 
78. Rezende, P.C.; Everett, B.M.; Brooks, M.M.; Vlachos, H.; Orchard, T.J.; Frye, R.L.; Bhatt, D.L.; Hlatky, M.A. Hypoglycemia and Elevated Troponin in Patients With Diabetes and Coronary Artery Disease. J. Am. Coll. Cardiol. 2018, 72, 1778-1786. [CrossRef]

79. Willeit, P.; Welsh, P.; Evans, J.D.; Tschiderer, L.; Boachie, C.; Jukema, J.W.; Ford, I.; Trompet, S.; Stott, D.J.; Kearney, P.M.; et al. High-Sensitivity Cardiac Troponin Concentration and Risk of First-Ever Cardiovascular Outcomes in 154,052 Participants. J. Am. Coll. Cardiol. 2017, 70, 558-568. [CrossRef]

80. Jia, X.; Sun, W.; Hoogeveen, R.C.; Nambi, V.; Matsushita, K.; Folsom, A.R.; Heiss, G.; Couper, D.J.; Solomon, S.D.; Boerwinkle, E.; et al. High-Sensitivity Troponin I and Incident Coronary Events, Stroke, Heart Failure Hospitalization, and Mortality in the ARIC Study. Circulation 2019, 139, 2642-2653. [CrossRef]

81. Jougasaki, M.; Burnett, J.C. Adrenomedullin: Potential in physiology and pathophysiology. Life Sci. 2000, 66, 855-872. [CrossRef]

82. Peacock, W.F. Novel biomarkers in acute heart failure: MR-pro-adrenomedullin. Clin. Chem. Lab. Med. 2014, 52, 1433-1435. [CrossRef]

83. Maisel, A.; Mueller, C.; Nowak, R.M.; Peacock, W.F.; Ponikowski, P.; Mockel, M.; Hogan, C.; Wu, A.H.; Richards, M.; Clopton, P.; et al. Midregion Prohormone Adrenomedullin and Prognosis in Patients Presenting with Acute Dyspnea. J. Am. Coll. Cardiol. 2011, 58, 1057-1067. [CrossRef]

84. Shah, R.V.; Truong, Q.A.; Gaggin, H.K.; Pfannkuche, J.; Hartmann, O.; Januzzi, J.L. Mid-regional pro-atrial natriuretic peptide and pro-adrenomedullin testing for the diagnostic and prognostic evaluation of patients with acute dyspnoea. Eur. Heart J. 2012, 33, 2197-2205. [CrossRef] [PubMed]

85. Vazquez-Montes, M.D.L.A.; Debray, T.P.A.; Taylor, K.S.; Speich, B.; Jones, N.; Collins, G.S.; Hobbs, F.D.R.R.; Magriplis, E.; Maruri-Aguilar, H.; Moons, K.G.M.; et al. UMBRELLA protocol: Systematic reviews of multivariable biomarker prognostic models developed to predict clinical outcomes in patients with heart failure. Diagn. Progn. Res. 2020, 4, 1-9. [CrossRef] [PubMed]

86. Huang, Z.; Zhong, J.; Ling, Y.; Zhang, Y.; Lin, W.; Tang, L.; Liu, J.; Li, S. Diagnostic value of novel biomarkers for heart failure. Herz 2018, 45, 65-78. [CrossRef] [PubMed]

87. Holmager, P.; Schou, M.; Egstrup, M.; Gustafsson, I.; Goetze, J.P.; Gustafsson, F.; Klausen, T.W.; Faber, J.; Kistorp, C. The Influence of Diabetes Mellitus on Midregional Proadrenomedullin Concentrations and Prognostic Value in Heart Failure Outpatients. J. Card. Fail. 2015, 21, 250-257. [CrossRef] [PubMed]

88. Gaborit, F.S.; Kistorp, C.; Kümler, T.; Hassager, C.; Tønder, N.; Iversen, K.; Kamstrup, P.R.; Faber, J.; Køber, L.; Schou, M. Early Stages of Obesity-related Heart Failure Are Associated with Natriuretic Peptide Deficiency and an Overall Lack of Neurohormonal Activation: The Copenhagen Heart Failure Risk Study. Glob. Heart 2020, 15, 25. [CrossRef]

89. Adela, R.; Banerjee, S.K. GDF-15 as a Target and Biomarker for Diabetes and Cardiovascular Diseases: A Translational Prospective. J. Diabetes Res. 2015, 2015, 490842. [CrossRef]

90. Kempf, T.; Guba-Quint, A.; Torgerson, J.; Magnone, M.C.; Haefliger, C.; Bobadilla, M.; Wollert, K.C. Growth differentiation factor 15 predicts future insulin resistance and impaired glucose control in obese nondiabetic individuals: Results from the XENDOS trial. Eur. J. Endocrinol. 2012, 167, 671-678. [CrossRef]

91. Berezin, A.E. Diabetes mellitus related biomarker: The predictive role of growth-differentiation factor-15. Diabetes Metab. Syndr. Clin. Res. Rev. 2016, 10, S154-S157. [CrossRef]

92. Echouffo-Tcheugui, J.B.; Daya, N.; Matsushita, K.; Wang, D.; Ndumele, C.E.; Al Rifai, M.; Hoogeveen, R.C.; Ballantyne, C.M.; Selvin, E. Growth Differentiation Factor (GDF)-15 and Cardiometabolic Outcomes among Older Adults: The Atherosclerosis Risk in Communities Study. Clin. Chem. 2021, 67, 653-661. [CrossRef]

93. Kempf, T.; von Haehling, S.; Peter, T.; Allhoff, T.; Cicoira, M.; Doehner, W.; Ponikowski, P.; Filippatos, G.S.; Rozentryt, P.; Drexler, H.; et al. Prognostic Utility of Growth Differentiation Factor-15 in Patients With Chronic Heart Failure. J. Am. Coll. Cardiol. 2007, 50, 1054-1060. [CrossRef] [PubMed]

94. Tuegel, C.; Katz, R.; Alam, M.; Bhat, Z.; Bellovich, K.; de Boer, I.; Brosius, F.; Gadegbeku, C.; Gipson, D.; Hawkins, J.; et al. GDF-15, Galectin 3, Soluble ST2, and Risk of Mortality and Cardiovascular Events in CKD. Am. J. Kidney Dis. 2018, 72, 519-528. [CrossRef]

95. Moutachakkir, M.; Hanchi, A.L.; Baraou, A.; Boukhira, A.; Chellak, S. Immunoanalytical characteristics of C-reactive protein and high sensitivity C-reactive protein. Ann. Biol. Clin. 2017, 75, 225-229. [CrossRef]

96. Liu, P.; Li, G.; Chen, Y.; Luo, H.; Huang, D.; Wang, Y.; Ge, S.; Zhang, J.; Xia, N. Chemiluminescent immunoassay for high-sensitivity C-reactive protein. Sheng Wu Gong Cheng Xue Bao 2010, 26, 1150-1156. [PubMed]

97. Bagherniya, M.; Khayyatzadeh, S.S.; Bakavoli, A.R.H.; Ferns, G.A.; Ebrahimi, M.; Safarian, M.; Nematy, M.; Ghayour-Mobarhan, M. Serum high-sensitive C-reactive protein is associated with dietary intakes in diabetic patients with and without hypertension: A cross-sectional study. Ann. Clin. Biochem. Int. J. Lab. Med. 2017, 55, 422-429. [CrossRef] [PubMed]

98. Pan, A.; Wang, Y.; Yuan, J.-M.; Koh, W.-P. High-sensitive C-reactive protein and risk of incident type 2 diabetes: A case-control study nested within the Singapore Chinese Health Study. BMC Endocr. Disord. 2017, 17, 1-8. [CrossRef] [PubMed]

99. Pfützner, A.; Standl, E.; Strotmann, H.-J.; Schulze, J.; Hohberg, C.; Lübben, G.; Pahler, S.; Schöndorf, T.; Forst, T. Association of high-sensitive C-reactive protein with advanced stage? Cell dysfunction and insulin resistance in patients with type 2 diabetes mellitus. Clin. Chem. Lab. Med. 2006, 44, 556-560. [CrossRef] [PubMed]

100. Noordam, R.; Oudt, C.; Bos, M.; Smit, R.; van Heemst, D. High-sensitivity C-reactive protein, low-grade systemic inflammation and type 2 diabetes mellitus: A two-sample Mendelian randomization study. Nutr. Metab. Cardiovasc. Dis. 2018, 28, 795-802. [CrossRef] 
101. Aryan, Z.; Ghajar, A.; Faghihi-Kashani, S.; Afarideh, M.; Nakhjavani, M.; Esteghamati, A. Baseline High-Sensitivity C-Reactive Protein Predicts Macrovascular and Microvascular Complications of Type 2 Diabetes: A Population-Based Study. Ann. Nutr. Metab. 2018, 72, 287-295. [CrossRef]

102. Gao, Y.; Liu, J.; Wang, W.; Gao, C.; Yu, C.; Liu, S.; Wu, J. An Elevated High-Sensitivity C-Reactive Protein Level Is Associated with Unfavorable Functional Outcomes of Small-Artery Occlusion in Patients without Diabetes. Eur. Neurol. 2017, 78, 48-55. [CrossRef] [PubMed]

103. Qiu, R.; Gao, Y.; Hou, D.; Wang, Y.; Yu, C.; Wang, W.; Liu, S.; Gao, C.; Tong, X.; Wu, J. Association between hs-CRP Levels and the Outcomes of Patients with Small-Artery Occlusion. Front. Aging Neurosci. 2016, 8, 191. [CrossRef]

104. Yang, Q.-Q.; Shao, D.; Li, J.; Yang, C.-L.; Fan, M.-H.; Cao, F.-L. Positive Association between Serum Levels of High-Sensitivity C-Reactive Protein and Depression/Anxiety in Female, but Not Male, Patients With Type 2 Diabetes Mellitus. Biol. Res. Nurs. 2019, 22, 178-187. [CrossRef] [PubMed]

105. Koenig, W. High-sensitivity C-reactive protein and atherosclerotic disease: From improved risk prediction to risk-guided therapy. Int. J. Cardiol. 2013, 168, 5126-5134. [CrossRef]

106. Dubrock, H.M.; AbouEzzeddine, O.F.; Redfield, M.M. High-sensitivity C-reactive protein in heart failure with preserved ejection fraction. PLoS ONE 2018, 13, e0201836. [CrossRef] [PubMed]

107. Al Aseri, Z.; Habib, S.S.; Marzouk, A. Predictive value of high sensitivity C-reactive protein on progression to heart failure occurring after the first myocardial infarction. Vasc. Health. Risk Manag. 2019, 15, 221-227. [CrossRef]

108. Kang, S.; Fan, L.-Y.; Chen, M.; Li, J.; Liu, Z.-M. Relationship of high-sensitivity C-reactive protein concentrations and systolic heart failure. Curr. Vasc. Pharmacol. 2017, 15, 1. [CrossRef] [PubMed]

109. Lourenço, P.; Pereira, J.; Ribeiro, A.; Ferreira-Coimbra, J.; Barroso, I.; Guimarães, J.-T.; Leite-Moreira, A.; Bettencourt, P. C-reactive protein decrease associates with mortality reduction only in heart failure with preserved ejection fraction. J. Cardiovasc. Med. 2019, 20, 23-29. [CrossRef]

110. Araújo, J.P.; Lourenço, P.; Azevedo, A.; Friões, F.; Rocha-Gonçalves, F.; Ferreira, A.; Bettencourt, P. Prognostic Value of HighSensitivity C-Reactive Protein in Heart Failure: A Systematic Review. J. Card. Fail. 2009, 15, 256-266. [CrossRef]

111. Lotierzo, M.; Dupuy, A.M.; Kalmanovich, E.; Roubille, F.; Cristol, J.P. sST2 as a value-added biomarker in heart failure. Clin. Chim. Acta 2020, 501, 120-130. [CrossRef]

112. Figal, D.A.P.; Lax, A.; Perez-Martinez, M.T.; Asensio-Lopez, M.D.C.; Sánchez-Más, J.; Network, O.B.O.G. Clinical relevance of sST2 in cardiac diseases. Clin. Chem. Lab. Med. 2016, 54, 29-35. [CrossRef]

113. Aimo, A.; Januzzi, J.L.; Bayes-Genis, A.; Vergaro, G.; Sciarrone, P.; Passino, C.; Emdin, M. Clinical and Prognostic Significance of sST2 in Heart Failure. J. Am. Coll. Cardiol. 2019, 74, 2193-2203. [CrossRef] [PubMed]

114. Emdin, M.; Aimo, A.; Vergaro, G.; Bayes-Genis, A.; Lupón, J.; Latini, R.; Meessen, J.; Anand, I.S.; Cohn, J.N.; Gravning, J.; et al. sST2 Predicts Outcome in Chronic Heart Failure Beyond NT-proBNP and High-Sensitivity Troponin T. J. Am. Coll. Cardiol. 2018, 72, 2309-2320. [CrossRef] [PubMed]

115. Barutaut, M.; Fournier, P.; Peacock, W.F.; Evaristi, M.-F.; Dambrin, C.; Caubère, C.; Koukoui, F.; Galinier, M.; Smih, F.; Rouet, P. sST2 adds to the prognostic value of Gal-3 and BNP in chronic heart failure. Acta Cardiol. 2020, 75, 739-747. [CrossRef] [PubMed]

116. Plawecki, M.; Morena, M.; Kuster, N.; Chenine, L.; Leray-Moragues, H.; Jover, B.; Fesler, P.; Lotierzo, M.; Dupuy, A.-M.; Klouche, K.; et al. sST2 as a New Biomarker of Chronic Kidney Disease-Induced Cardiac Remodeling: Impact on Risk Prediction. Mediat. Inflamm. 2018, 2018, 3952526. [CrossRef]

117. Huang, A.; Qi, X.; Hou, W.; Qi, Y.; Zhao, N.; Liu, K. Prognostic value of sST2 and NT-proBNP at admission in heart failure with preserved, mid-ranged and reduced ejection fraction. Acta Cardiol. 2017, 73, 41-48. [CrossRef] [PubMed]

118. Lichtenauer, M.; Jirak, P.; Wernly, B.; Paar, V.; Rohm, I.; Jung, C.; Schernthaner, C.; Kraus, J.; Motloch, L.J.; Yilmaz, A.; et al. A comparative analysis of novel cardiovascular biomarkers in patients with chronic heart failure. Eur. J. Intern. Med. 2017, 44, 31-38. [CrossRef]

119. Dong, R.; Zhang, M.; Hu, Q.; Zheng, S.; Soh, A.; Zheng, Y.; Yuan, H. Galectin-3 as a novel biomarker for disease diagnosis and a target for therapy. Int. J. Mol. Med. 2018, 41, 599-614. [CrossRef] [PubMed]

120. Sciacchitano, S.; Lavra, L.; Morgante, A.; Ulivieri, A.; Magi, F.; De Francesco, G.P.; Bellotti, C.; Salehi, L.B.; Ricci, A. Galectin-3: One Molecule for an Alphabet of Diseases, from A to Z. Int. J. Mol. Sci. 2018, 19, 379. [CrossRef]

121. Suthahar, N.; Meijers, W.C.; Silljé, H.H.; Ho, J.E.; Liu, F.-T.; De Boer, R.A. Galectin-3 Activation and Inhibition in Heart Failure and Cardiovascular Disease: An Update. Theranostics 2018, 8, 593-609. [CrossRef]

122. Funasaka, T.; Raz, A.; Nangia-Makker, P. Galectin-3 in angiogenesis and metastasis. Glycobiology 2014, 24, 886-891. [CrossRef] [PubMed]

123. Martínez-Martínez, E.; Brugnolaro, C.; Ibarrola, J.; Ravassa, S.; Buonafine, M.; López, B.; Fernández-Celis, A.; Querejeta, R.; Santamaria, E.; Fernández-Irigoyen, J.; et al. CT-1 (Cardiotrophin-1)-Gal-3 (Galectin-3) Axis in Cardiac Fibrosis and Inflammation. Hypertension 2019, 73, 602-611. [CrossRef] [PubMed]

124. Vora, A.; De Lemos, J.A.; Ayers, C.; Grodin, J.L.; Lingvay, I. Association of Galectin-3 With Diabetes Mellitus in the Dallas Heart Study. J. Clin. Endocrinol. Metab. 2019, 104, 4449-4458. [CrossRef]

125. Tan, K.C.B.; Cheung, C.-L.; Lee, A.C.H.; Lam, J.K.Y.; Wong, Y.; Shiu, S.W.M. Galectin-3 is independently associated with progression of nephropathy in type 2 diabetes mellitus. Diabetologia 2018, 61, 1212-1219. [CrossRef] 
126. Tan, K.C.B.; Cheung, C.-L.; Lee, A.C.; Lam, J.K.; Wong, Y.; Shiu, S.W. Galectin-3 and risk of cardiovascular events and all-cause mortality in type 2 diabetes. Diabetes Metab. Res. Rev. 2018, 35, e3093. [CrossRef]

127. Gehlken, C.; Suthahar, N.; Meijers, W.C.; de Boer, R.A. Galectin-3 in Heart Failure. Heart Fail. Clin. 2018, 14, 75-92. [CrossRef] [PubMed]

128. Romero, A.; Gabius, H.-J. Galectin-3: Is this member of a large family of multifunctional lectins (already) a therapeutic target? Expert Opin. Ther. Targets 2019, 23, 819-828. [CrossRef]

129. Pugliese, G.; Iacobini, C.; Ricci, C.; Fantauzzi, C.B.; Menini, S. Galectin-3 in diabetic patients. Clin. Chem. Lab. Med. 2014, 52, 1413-1423. [CrossRef] [PubMed]

130. Zhong, X.; Qian, X.; Chen, G.; Song, X. The role of galectin-3 in heart failure and cardiovascular disease. Clin. Exp. Pharmacol. Physiol. 2019, 46, 197-203. [CrossRef]

131. Oikonomou, E.; Karlis, D.; Tsalamadris, S.; Siasos, G.; Chrysohoou, C.; Vogiatzi, G.; Dimitropoulos, S.; Charalambous, G.; Kouskouni, E.; Tousoulis, D. Galectin-3 and Arterial Stiffness in Patients with Heart Failure: A Pilot Study. Curr. Vasc. Pharmacol. 2019, 17, 396-400. [CrossRef]

132. Gaggin, H.K.; Januzzi, J.L. Biomarkers and diagnostics in heart failure. Biochim. Biophys. Acta Mol. Basis Dis. 2013, 1832, 2442-2450. [CrossRef] [PubMed]

133. De Boer, R.A.; Edelmann, F.; Cohen-Solal, A.; Mamas, M.A.; Maisel, A.; Pieske, B. Galectin-3 in heart failure with preserved ejection fraction. Eur. J. Heart Fail. 2013, 15, 1095-1101. [CrossRef] [PubMed]

134. Trippel, T.D.; Mende, M.; Düngen, H.; Hashemi, D.; Petutschnigg, J.; Nolte, K.; Herrmann-Lingen, C.; Binder, L.; Hasenfuss, G.; Pieske, B.; et al. The diagnostic and prognostic value of galectin-3 in patients at risk for heart failure with preserved ejection fraction: Results from the DIAST-CHF study. ESC Heart Fail. 2021, 8, 829-841. [CrossRef]

135. Gocer, H.; Günday, M.; Ünal, M. Plasma galectin-3 as a biomarker for clinical staging of heart failure: A cross-sectional evaluation of 100 cases. Clin. Ther 2019, 170, e267-e271.

136. Chen, Y.-S.; Gi, W.-T.; Liao, T.-Y.; Lee, M.-T.G.; Lee, S.-H.; Hsu, W.-T.; Chang, S.-S.; Lee, C.-C. Using the galectin-3 test to predict mortality in heart failure patients: A systematic review and meta-analysis. Biomarkers Med. 2016, 10, 329-342. [CrossRef]

137. Srivatsan, V.; George, M.; Shanmugam, E. Utility of galectin-3 as a prognostic biomarker in heart failure: Where do we stand? Eur. J. Prev. Cardiol. 2015, 22, 1096-1110. [CrossRef]

138. Mueller, T.; Gegenhuber, A.; Leitner, I.; Poelz, W.; Haltmayer, M.; Dieplinger, B. Diagnostic and prognostic accuracy of galectin-3 and soluble ST2 for acute heart failure. Clin. Chim. Acta 2016, 463, 158-164. [CrossRef]

139. Rose-John, S. Interleukin-6 Family Cytokines. Cold Spring Harb. Perspect. Biol. 2018, 10, a028415. [CrossRef]

140. Stejskal, D.; Ruzicka, V. Cardiotrophin-1 Review. Biomed. Pap. 2008, 152, 9-19. [CrossRef]

141. Kolijn, D.; Pabel, S.; Tian, Y.; Lódi, M.; Herwig, M.; Carrizzo, A.; Zhazykbayeva, S.; Kovács, A.; Fülöp, G.Á.; Falcão-Pires, I.; et al. Empagliflozin improves endothelial and cardiomyocyte function in human heart failure with preserved ejection fraction via reduced pro-inflammatory-oxidative pathways and protein kinase G $\alpha$ oxidation. Cardiovasc. Res. 2021, 117, 495-507. [CrossRef]

142. Kashiwagi, A.; Araki, S.; Maegawa, H. Sodium-glucose cotransporter 2 inhibitors represent a paradigm shift in the prevention of heart failure in type 2 diabetes patients. J. Diabetes Investig. 2021, 12, 6-20. [CrossRef] [PubMed]

143. Lee, M.M.; Petrie, M.C.; McMurray, J.J.; Sattar, N. How Do SGLT2 (Sodium-Glucose Cotransporter 2) Inhibitors and GLP-1 (Glucagon-Like Peptide-1) Receptor Agonists Reduce Cardiovascular Outcomes? Arter. Thromb. Vasc. Biol. 2020, 40, 506-522. [CrossRef]

144. Ferreira, J.M.; Ferreira, S.M.; Ferreira, M.J.; Falcão-Pires, I. Circulating Biomarkers of Collagen Metabolism and Prognosis of Heart Failure with Reduced or Mid-Range Ejection Fraction. Curr. Pharm. Des. 2017, 23, 3217-3223. [CrossRef] [PubMed]

145. Zile, M.R.; Jhund, P.S.; Baicu, C.F.; Claggett, B.L.; Pieske, B.; Voors, A.A.; Prescott, M.F.; Shi, V.; Lefkowitz, M.; McMurray, J.J.; et al. Plasma Biomarkers Reflecting Profibrotic Processes in Heart Failure With a Preserved Ejection Fraction. Circ. Heart Fail. 2016, 9 , e002551. [CrossRef] [PubMed]

146. Kaye, D.M.; Khammy, O.; Mariani, J.; Maeder, M.T. Relationship of circulating matrix biomarkers to myocardial matrix metabolism in advanced heart failure. Eur. J. Heart Fail. 2013, 15, 292-298. [CrossRef] [PubMed]

147. Dupuy, A.M.; Kuster, N.; Curinier, C.; Huet, F.; Plawecki, M.; Solecki, K.; Roubille, F.; Cristol, J.P. Exploring collagen remodeling and regulation as prognosis biomarkers in stable heart failure. Clin. Chim. Acta 2019, 490, 167-171. [CrossRef]

148. Sanchis, L.; Andrea, R.; Falces, C.; Llopis, J.; Morales-Ruiz, M.; López-Sobrino, T.; Pérez-Villa, F.; Sitges, M.; Sabate, M.; Brugada, J. Prognosis of new-onset heart failure outpatients and collagen biomarkers. Eur. J. Clin. Investig. 2015, 45, 842-849. [CrossRef]

149. Duprez, D.A.; Gross, M.D.; Kizer, J.R.; Ix, J.H.; Hundley, W.G.; Jacobs, D.R. Predictive Value of Collagen Biomarkers for Heart Failure With and Without Preserved Ejection Fraction: MESA (Multi-Ethnic Study of Atherosclerosis). J. Am. Heart Assoc. 2018, 7 , e007885. [CrossRef]

150. Yang, J.; Savvatis, K.; Kang, J.S.; Fan, P.; Zhong, H.; Schwartz, K.; Barry, V.; Mikels-Vigdal, A.; Karpinski, S.; Kornyeyev, D.; et al. Targeting LOXL2 for cardiac interstitial fibrosis and heart failure treatment. Nat. Commun. 2016, 7, 13710. [CrossRef]

151. Ferreira, J.P.; Verdonschot, J.; Collier, T.; Wang, P.; Pizard, A.; Bär, C.; Björkman, J.; Boccanelli, A.; Butler, J.; Clark, A.; et al. Proteomic Bioprofiles and Mechanistic Pathways of Progression to Heart Failure. Circ. Heart Fail. 2019, 12, e005897. [CrossRef]

152. Ravassa, S.; Ballesteros, G.; López, B.; Ramos, P.; Bragard, J.; González, A.; Moreno, M.U.; Querejeta, R.; Vives, E.; García-Bolao, I.; et al. Combination of Circulating Type I Collagen-Related Biomarkers Is Associated with Atrial Fibrillation. J. Am. Coll. Cardiol. 2019, 73, 1398-1410. [CrossRef] [PubMed] 
153. Michalski, B.; Trzciński, P.; Kupczyńska, K.; Miśkowiec, D.; Pęczek, L.; Nawrot, B.; Lipiec, P.; Kasprzak, J.D. The differences in the relationship between diastolic dysfunction, selected biomarkers and collagen turn-over in heart failure patients with preserved and reduced ejection fraction. Cardiol. J. 2017, 24, 35-42. [CrossRef]

154. Löfsjögård, J.; Kahan, T.; Díez, J.; López, B.; González, A.; Edner, M.; Henriksson, P.; Mejhert, M.; Persson, H. Biomarkers of collagen type I metabolism are related to B-type natriuretic peptide, left ventricular size, and diastolic function in heart failure. J. Cardiovasc. Med. 2014, 15, 463-469. [CrossRef]

155. Topf, A.; Mirna, M.; Ohnewein, B.; Jirak, P.; Kopp, K.; Fejzic, D.; Haslinger, M.; Motloch, L.J.; Hoppe, U.C.; Berezin, A.; et al. The Diagnostic and Therapeutic Value of Multimarker Analysis in Heart Failure. An Approach to Biomarker-Targeted Therapy. Front. Cardiovasc. Med. 2020, 7, 579567. [CrossRef] [PubMed]

156. Düngen, H.-D.; Tscholl, V.; Obradovic, D.; Radenovic, S.; Matic, D.; Bright, L.M.; Tahirovic, E.; Marx, A.; Inkrot, S.; Hashemi, D.; et al. Prognostic performance of serial in-hospital measurements of copeptin and multiple novel biomarkers among patients with worsening heart failure: Results from the MOLITOR study. ESC Heart Fail. 2018, 5, 288-296. [CrossRef]

157. Zhang, M.; Meng, Q.; Qi, X.; Han, Q.; Qi, X.; Wang, F.; Du, B. Comparison of multiple biomarkers for mortality prediction in patients with acute heart failure of ischemic and nonischemic etiology. Biomarkers Med. 2018, 12, 1207-1217. [CrossRef] [PubMed]

158. Pandey, A.; Vaduganathan, M.; Patel, K.V.; Ayers, C.; Ballantyne, C.M.; Kosiborod, M.N.; Carnethon, M.; DeFilippi, C.; McGuire, D.K.; Khan, S.S.; et al. Biomarker-Based Risk Prediction of Incident Heart Failure in Pre-Diabetes and Diabetes. JACC Heart Fail. 2021, 9, 215-223. [CrossRef]

159. Berezin, A.E.; Kremzer, A.A.; Samura, T.; Berezina, T. Altered signature of apoptotic endothelial cell-derived microvesicles predicts chronic heart failure phenotypes. Biomarkers Med. 2019, 13, 737-750. [CrossRef]

160. Maisel, A.S.; Krishnaswamy, P.; Nowak, R.M.; Mccord, J.; Hollander, J.E.; Duc, P.; Omland, T.; Storrow, A.B.; Abraham, W.T.; Wu, A.H.; et al. Rapid Measurement of B-Type Natriuretic Peptide in the Emergency Diagnosis of Heart Failure. N. Engl. J. Med. 2002, 347, 161-167. [CrossRef]

161. Wieczorek, S.J.; Wu, A.H.; Christenson, R.; Krishnaswamy, P.; Gottlieb, S.; Rosano, T.; Hager, D.; Gardetto, N.; Chiu, A.; Bailly, K.R.; et al. A rapid B-type natriuretic peptide assay accurately diagnoses left ventricular dysfunction and heart failure: A multicenter evaluation. Am. Heart J. 2002, 144, 834-839. [CrossRef]

162. Rawlins, M.L.; Owen, W.E.; Roberts, W.L. Performance Characteristics of Four Automated Natriuretic Peptide Assays. Am. J. Clin. Pathol. 2005, 123, 439-445. [CrossRef]

163. Wu, A.H.; Packer, M.; Smith, A.; Bijou, R.; Fink, D.; Mair, J.; Wallentin, L.; Johnston, N.; Feldcamp, C.S.; Haverstick, D.M.; et al. Analytical and Clinical Evaluation of the Bayer ADVIA Centaur Automated B-Type Natriuretic Peptide Assay in Patients with Heart Failure: A Multisite Study. Clin. Chem. 2004, 50, 867-873. [CrossRef]

164. Mueller, T.; Gegenhuber, A.; Poelz, W.; Haltmayer, M. Preliminary Evaluation of the AxSYM B-Type Natriuretic Peptide (BNP) Assay and Comparison with the ADVIA Centaur BNP Assay. Clin. Chem. 2004, 50, 1104-1106. [CrossRef] [PubMed]

165. Barak, M.; Weinberger, R.; Marcusohn, J.; Froom, P. Harmonization of the Bayer ADVIA Centaur and Abbott AxSYM automated B-type natriuretic peptide assay in patients on hemodialysis. Clin. Chem. Lab. Med. 2005, 43, 554-556. [CrossRef] [PubMed]

166. Lingervelder, D.; Koffijberg, H.; Kusters, R.; Ijzerman, M.J. Point-of-care testing in primary care: A systematic review on implementation aspects addressed in test evaluations. Int. J. Clin. Pract. 2019, 73, e13392. [CrossRef]

167. Müller-Bardorff, M.; Freitag, H.; Scheffold, T.; Remppis, A.; Kübler, W.; Katus, H.A. Development and Characterization of a Rapid Assay for Bedside Determinations of Cardiac Troponin T. Circulation 1995, 92, 2869-2875. [CrossRef] [PubMed]

168. Alp, N.; Bell, J.; Shahi, M. A rapid troponin-I-based protocol for assessing acute chest pain. QJM Int. J. Med. 2001, 94, 687-694. [CrossRef]

169. Ramparany, L.; Ramirez, J.; Nizou, J.-Y.; Le Saux, D.; Richard, V.; Talarmin, A. Evaluation of Four Rapid Immunochromatographic Tests for the Detection of Cardiac Troponin I. Clin. Vaccine Immunol. 2011, 18, 414-417. [CrossRef] [PubMed]

170. Wettersten, N.; Maisel, A.; University of California San Diego; System, L.J.V.A.S.D.H. Role of Cardiac Troponin Levels in Acute Heart Failure. Card. Fail. Rev. 2015, 1, 102-106. [CrossRef] [PubMed]

171. Ishimitsu, T.; Kojima, M.; Kangawa, K.; Hino, J.; Matsuoka, H.; Kitamura, K.; Eto, T.; Matsuo, H. Genomic Structure of Human Adrenomedullin Gene. Biochem. Biophys. Res. Commun. 1994, 203, 631-639. [CrossRef] [PubMed]

172. Jougasaki, M.; Wei, C.-M.; McKinley, L.J.; Burnett, J.C. Elevation of Circulating and Ventricular Adrenomedullin in Human Congestive Heart Failure. Circulation 1995, 92, 286-289. [CrossRef] [PubMed]

173. Gegenhuber, A.; Struck, J.; Dieplinger, B.; Poelz, W.; Pacher, R.; Morgenthaler, N.G.; Bergmann, A.; Haltmayer, M.; Mueller, T. Comparative Evaluation of B-Type Natriuretic Peptide, Mid-Regional Pro-A-type Natriuretic Peptide, Mid-Regional ProAdrenomedullin, and Copeptin to Predict 1-Year Mortality in Patients With Acute Destabilized Heart Failure. J. Card. Fail. 2007, 13, 42-49. [CrossRef] [PubMed]

174. Lewis, L.K.; Smith, M.W.; Yandle, T.G.; Richards, A.M.; Nicholls, M.G. Adrenomedullin (1-52) measured in human plasma by radioimmunoassay: Plasma concentration, adsorption, and storage. Clin. Chem. 1998, 44, 571-577. [CrossRef] [PubMed]

175. Struck, J.; Tao, C.; Morgenthaler, N.G.; Bergmann, A. Identification of an Adrenomedullin precursor fragment in plasma of sepsis patients. Peptides 2004, 25, 1369-1372. [CrossRef]

176. Morgenthaler, N.G.; Struck, J.; Alonso, C.; Bergmann, A. Measurement of Midregional Proadrenomedullin in Plasma with an Immunoluminometric Assay. Clin. Chem. 2005, 51, 1823-1829. [CrossRef] 
177. Izumiya, Y.; Hanatani, S.; Kimura, Y.; Takashio, S.; Yamamoto, E.; Kusaka, H.; Tokitsu, T.; Rokutanda, T.; Araki, S.; Tsujita, K.; et al. Growth Differentiation Factor-15 Is a Useful Prognostic Marker in Patients with Heart Failure with Preserved Ejection Fraction. Can. J. Cardiol. 2014, 30, 338-344. [CrossRef] [PubMed]

178. Wollert, K.C.; Kempf, T.; Wallentin, L. Growth Differentiation Factor 15 as a Biomarker in Cardiovascular Disease. Clin. Chem. 2017, 63, 140-151. [CrossRef]

179. Black, S.; Kushner, I.; Samols, D. C-reactive Protein. J. Biol. Chem. 2004, 279, 48487-48490. [CrossRef] [PubMed]

180. Joshi, A.; Perin, D.P.; Gehle, A.; Nsiah-Kumi, P.A. Feasibility of using C-reactive protein for point-of-care testing. Technol. Health Care 2013, 21, 233-240. [CrossRef]

181. Lindström, J.; Nordeman, L.; Hagstrom, B. What a difference a CRP makes. A prospective observational study on how point-ofcare C-reactive protein testing influences antibiotic prescription for respiratory tract infections in Swedish primary health care. Scand. J. Prim. Health Care 2015, 33, 275-282. [CrossRef]

182. Prajapati, A.; Verma, N.; Pandya, A. Highly sensitive vertical flow based point-of-care immunokit for rapid and early detection of human CRP as a cardiovascular risk factor. Biomed. Microdevices 2020, 22, 28. [CrossRef]

183. Patti, G.; Mangiacapra, F.; Ricottini, E.; Cannatà, A.; Cavallari, I.; Vizzi, V.; D’Ambrosio, A.; Dicuonzo, G.; Di Sciascio, G. Correlation of Platelet Reactivity and C-Reactive Protein Levels to Occurrence of Peri-Procedural Myocardial Infarction in Patients Undergoing Percutaneous Coronary Intervention (from the ARMYDA-CRP Study). Am. J. Cardiol. 2013, 111, 1739-1744. [CrossRef] [PubMed]

184. Park, D.-W.; Lee, S.-W.; Yun, S.-C.; Song, H.-G.; Ahn, J.-M.; Lee, J.-Y.; Kim, W.-J.; Kang, S.-J.; Kim, Y.-H.; Lee, C.W.; et al. A Point-of-Care Platelet Function Assay and C-Reactive Protein for Prediction of Major Cardiovascular Events After Drug-Eluting Stent Implantation. J. Am. Coll. Cardiol. 2011, 58, 2630-2639. [CrossRef]

185. O'Meara, E.; Prescott, M.F.; Claggett, B.; Rouleau, J.L.; Chiang, L.-M.; Solomon, S.D.; Packer, M.; McMurray, J.J.; Zile, M.R Independent Prognostic Value of Serum Soluble ST2 Measurements in Patients With Heart Failure and a Reduced Ejection Fraction in the PARADIGM-HF Trial (Prospective Comparison of ARNI With ACEI to Determine Impact on Global Mortality and Morbidity in Heart Failure). Circ. Heart Fail. 2018, 11, e004446. [CrossRef] [PubMed]

186. Krum, H. Prospective Comparison of ARNi with ACE-I to Determine Impact on Global Mortality and Morbidity in Heart Failure (PARADIGM-HF): Paragon of a study or further investigation paramount? Circulation 2015, 131, 11-12. [CrossRef] [PubMed]

187. Gruson, D.; Ferracin, B.; Ahn, S.; Rousseau, M.F. Testing for Soluble ST2 in Heart Failure Patients: Reliability of a Point of Care Method. Clin. Lab. 2017, 63, 141-145. [CrossRef] [PubMed]

188. Dieplinger, B.; Egger, M.; Gegenhuber, A.; Haltmayer, M.; Mueller, T. Analytical and clinical evaluation of a rapid quantitative lateral flow immunoassay for measurement of soluble ST2 in human plasma. Clin. Chim. Acta 2015, 451, 310-315. [CrossRef]

189. Anand, I.S.; Rector, T.S.; Kuskowski, M.; Adourian, A.; Muntendam, P.; Cohn, J.N. Baseline and serial measurements of galectin-3 in patients with heart failure: Relationship to prognosis and effect of treatment with valsartan in the Val-HeFT. Eur. J. Heart Fail. 2013, 15, 511-518. [CrossRef] [PubMed]

190. Van Der Velde, A.R.; Gullestad, L.; Ueland, T.; Aukrust, P.; Guo, Y.; Adourian, A.; Muntendam, P.; Van Veldhuisen, D.J.; De Boer, R.A. Prognostic Value of Changes in Galectin-3 Levels Over Time in Patients With Heart Failure. Circ. Heart Fail. 2013, 6, $219-226$. [CrossRef]

191. Gaze, D.C.; Prante, C.; Dreier, J.; Knabbe, C.; Collet, C.; Launay, J.-M.; Franekova, J.; Jabor, A.; Lennartz, L.; Shih, J.; et al. Analytical evaluation of the automated galectin-3 assay on the Abbott ARCHITECT immunoassay instruments. Clin. Chem. Lab. Med. 2014, 52, 919-926. [CrossRef]

192. La'Ulu, S.L.; Apple, F.S.; Murakami, M.M.; Ler, R.; Roberts, W.L.; Straseski, J.A. Performance characteristics of the ARCHITECT Galectin-3 assay. Clin. Biochem. 2013, 46, 119-122. [CrossRef] [PubMed]

193. Sygitowicz, G.; Tomaniak, M.; Filipiak, K.J.; Kołtowski, Ł.; Sitkiewicz, D. Galectin-3 in Patients with Acute Heart Failure: Preliminary Report on First Polish Experience. Adv. Clin. Exp. Med. 2016, 25, 617-623. [CrossRef]

194. Gruson, D.; Mancini, M.; Ahn, S.; Rousseau, M. Galectin-3 testing: Validity of a novel automated assay in heart failure patients with reduced ejection fraction. Clin. Chim. Acta 2014, 429, 189-193. [CrossRef] [PubMed]

195. Markousis-Mavrogenis, G.; Tromp, J.; Ouwerkerk, W.; Devalaraja, M.; Anker, S.D.; Cleland, J.G.; Dickstein, K.; Filippatos, G.S.; Van Der Harst, P.; Lang, C.C.; et al. The clinical significance of interleukin-6 in heart failure: Results from the BIOSTAT-CHF study. Eur. J. Heart Fail. 2019, 21, 965-973. [CrossRef]

196. Huang, D.; Ying, H.; Jiang, D.; Liu, F.; Tian, Y.; Du, C.; Zhang, L.; Pu, X. Rapid and sensitive detection of interleukin-6 in serum via time-resolved lateral flow immunoassay. Anal. Biochem. 2020, 588, 113468. [CrossRef]

197. Chaemsaithong, P.; Romero, R.; Korzeniewski, S.J.; Dong, Z.; Yeo, L.; Hassan, S.S.; Kim, Y.M.; Yoon, B.H.; Chaiworapongsa, T. A point of care test for the determination of amniotic fluid interleukin-6 and the chemokine CXCL-10/IP-10. J. Matern. Neonatal Med. 2015, 28, 1510-1519. [CrossRef] [PubMed]

198. Chaemsaithong, P.; Romero, R.; Docheva, N.; Chaiyasit, N.; Bhatti, G.; Pacora, P.; Hassan, S.S.; Yeo, L.; Erez, O. Comparison of rapid MMP-8 and interleukin-6 point-of-care tests to identify intra-amniotic inflammation/infection and impending preterm delivery in patients with preterm labor and intact membranes. J. Matern. Neonatal Med. 2018, 31, 228-244. [CrossRef]

199. Louzao-Martinez, L.; Vink, A.; Harakalova, M.; Asselbergs, F.W.; Verhaar, M.C.; Cheng, C. Characteristic adaptations of the extracellular matrix in dilated cardiomyopathy. Int. J. Cardiol. 2016, 220, 634-646. [CrossRef] 
200. Gunja-Smith, Z.; Morales, A.R.; Romanelli, R.; Woessner, J.F. Remodeling of human myocardial collagen in idiopathic dilated cardiomyopathy. Role of metalloproteinases and pyridinoline cross-links. Am. J. Pathol. 1996, 148, 1639-1648.

201. Kai, H.; Ikeda, H.; Yasukawa, H.; Kai, M.; Seki, Y.; Kuwahara, F.; Ueno, T.; Sugi, K.; Imaizumi, T. Peripheral blood levels of matrix metalloproteases-2 and -9 are elevated in patients with acute coronary syndromes. J. Am. Coll. Cardiol. 1998, 32, 368-372. [CrossRef]

202. Mihailovici, A.R.; Deliu, R.C.; Mărgăritescu, C.; Simionescu, C.E.; Donoiu, I.; Istrătoaie, O.; Tudoraşcu, D.R.; Târtea, E.A.; Gheonea, D.I. Collagen I and III, MMP-1 and TIMP-1 immunoexpression in dilated cardiomyopathy. Rom. J. Morphol. Embryol. 2017, 58, 777-781. [PubMed]

203. Lubos, E.; Schnabel, R.; Rupprecht, H.J.; Bickel, C.; Messow, C.-M.; Prigge, S.; Cambien, F.; Tiret, L.; Münzel, T.; Blankenberg, S. Prognostic value of tissue inhibitor of metalloproteinase- 1 for cardiovascular death among patients with cardiovascular disease: Results from the AtheroGene study. Eur. Heart J. 2005, 27, 150-156. [CrossRef] [PubMed]

204. Sorsa, T.; Tervahartiala, T.; Leppilahti, J.; Hernandez, M.; Gamonal, J.; Tuomainen, A.M.; Lauhio, A.; Pussinen, P.J.; Mäntylä, P. Collagenase-2 (MMP-8) as a point-of-care biomarker in periodontitis and cardiovascular diseases. Therapeutic response to non-antimicrobial properties of tetracyclines. Pharmacol. Res. 2011, 63, 108-113. [CrossRef]

205. Leppilahti, J.; Ahonen, M.-M.; Hernández, M.; Munjal, S.; Netuschil, L.; Uitto, V.-J.; Sorsa, T.; Mäntylä, P. Oral rinse MMP-8 point-of-care immuno test identifies patients with strong periodontal inflammatory burden. Oral Dis. 2010, 17, 115-122. [CrossRef] [PubMed]

206. Florea, V.G.; Anand, I.S. Troponin T and Plasma Collagen Peptides in Heart Failure. Circ. Heart Fail. 2012, 5, 394-397. [CrossRef] [PubMed] 